\title{
First steps towards the assimilation of IASI ozone data into the MOCAGE-PALM system
}

\author{
S. Massart ${ }^{1}$, C. Clerbaux ${ }^{2}$, D. Cariolle ${ }^{1}$, A. Piacentini ${ }^{1}$, S. Turquety ${ }^{2}$, and J. Hadji-Lazaro ${ }^{2}$ \\ ${ }^{1}$ URA CNRS/CERFACS No. 1875, 42 avenue Gaspard Coriolis, 31057 Toulouse, France \\ ${ }^{2}$ Université Pierre et Marie Curie-Paris 6, CNRS 8190, LATMOS/IPSL, Paris, France \\ Received: 7 January 2009 - Published in Atmos. Chem. Phys. Discuss.: 10 March 2009 \\ Revised: 17 June 2009 - Accepted: 17 July 2009 - Published: 28 July 2009
}

\begin{abstract}
With the use of data assimilation, we study the quality of the Infrared Atmospheric Sounding Interferometer (IASI) total ozone column measurements. The IASI data are provided by the inversion of IASI radiances performed at the Laboratoire ATmosphères, Milieux, Observations Spatiales (LATMOS). This data set is initially compared on a five-month period to a three-dimensional time varying ozone field that we take as a reference. This reference field results from the combined assimilation of ozone profiles from the Microwave Limb Sounder (MLS) instrument and of total ozone columns from the SCanning Imaging Absorption spectroMeter for Atmospheric CHartographY (SCIAMACHY) instrument. It has low systematic and random errors when compared to ozonesondes and Ozone Monitoring Instrument (OMI) data. The comparison shows that on average, the LATMOS-IASI data tends to overestimate the total ozone columns by $2 \%$ to $8 \%$. The random observation error of the LATMOS-IASI data is estimated to about $7 \%$, except over polar regions and deserts where it is higher. The daytime data have generally lower biases but higher random error than the nighttime data. Using this information, the LATMOS-IASI data are then assimilated, combined with the MLS data. This first LATMOS-IASI data assimilation experiment shows that the resulting analysis is quite similar to the one obtained from the combined MLS and SCIAMACHY data assimilation. The differences are mainly due to the lack of SCIAMACHY measurements during polar night, and to the higher LATMOS-IASI random errors especially over the southern polar region.
\end{abstract}

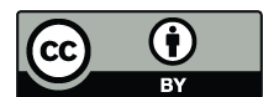

Correspondence to: S. Massart (massart@cerfacs.fr)

\section{Introduction}

Modern low-Earth orbits (LEO) satellites carry on board a new generation of instruments with higher resolution in frequency and space sampling and with a broader spectral coverage. They perform very accurate observations of numerous parameters of the atmosphere: vertical profiles of temperature, humidity and trace gases measurements for example. Moreover, flying at low orbital altitude, the LEO satellites can achieve a global coverage in less than one day. Recently, the LEO MetOp-A satellite, with the Infrared Atmospheric Sounding Interferometer (IASI) onboard was launched. At an altitude of $817 \mathrm{~km}$, MetOp-A takes about $100 \mathrm{~min}$ to complete one orbit. During that time, the Earth has rotated by around $25^{\circ}$. This means that a complete mapping of the Earth is obtained in about one day.

IASI is one of the five European new generation instruments onboard MetOp-A. It measures the infrared (IR) radiation emitted from the surface of the Earth and the atmosphere. Due to its very high resolution, data of excellent accuracy and resolution are obtained. These data are mainly atmospheric humidity and temperature profiles in the troposphere and lower stratosphere, as well as the concentration of the chemical components (methane, carbon monoxide, ozone) that play a key role in atmospheric chemistry (Clerbaux et al., 2009). Aside the exploitation of IASI for improving short-term weather forecasting, this instrument can also be used to monitor the atmospheric content of the chemical species or to contribute to the improvement of short-term chemical weather forecasting systems.

At the time this article is written, IASI is a new instrument and retrieval algorithms are still in a development stage. The first main objective of this work is therefore to obtain a crossvalidation of the IASI retrieval algorithm developed by the Laboratoire ATmosphères, Milieux, Observations Spatiales

Published by Copernicus Publications on behalf of the European Geosciences Union. 
(LATMOS) (Turquety et al., 2004). One way to validate satellite data is to perform detailed comparisons of their retrievals with independent data sets. Those reference data sets generally result from in situ measurements. Such intercomparisons have been performed by Migliorini at al. (2004) for the ozone measurements from the Michelson Interferometer for Passive Atmospheric Sounding (MIPAS) instrument, and for the IASI temperature and water vapour retrievals, by Pougatchev et al. (2009). Unfortunately, in most cases, the reference data have different characteristics, non-negligible errors, and perform their measurements at close but different times and locations than the data to be validated. In order to obtain systematically a reference value in a close neighbour of each observation, the reference data can be complemented with the outputs of a numerical model. This was done for example by Ricaud et al. (2009) who compared total columns of nitrous oxide from IASI retrievals to the outputs of the 3-D Chemistry Transport Model (CTM) Modèle de Chimie Atmosphérique à Grande Échelle (MOCAGE). In order to further reduce the errors of the reference data, one can also use the outputs from a data assimilation system. Massart et al. (2007) applied this methodology to evaluate the quality of the ozone measurements from the Sub-Millimetre Radiometer (SMR) instrument.

Even if the use of data assimilation for atmospheric chemistry is quite recent if compared to other geophysical applications, these techniques are nowadays robust and efficient enough to be used for scientific purposes (Lahoz et al., 2007a). The early assimilation systems for the atmospheric chemistry were mainly focused on stratospheric constituents, especially ozone, with the first implementation of an ozone assimilation system made at the NCEP at the end of the 1990s (Caplan et al., 1997). The current assimilation systems are built on top either of Numerical Weather Prediction (NWP) systems (Derber et al., 1998; Dethof, 2003) or CTMs (Errera and Fonteyn, 2001; Eskes et al., 2003). The advantage of using a CTM for the assimilation process is that a CTM has generally a more complex representation of chemical processes compared to the representation included into NWP systems. Thus, CTM based assimilation systems are often used for the analysis and the forecast of chemical constituents. Most of them are based on satellite level 2 products that include vertical profiles of trace gases or partial and total column determination. For the assimilation of the MIPAS ozone profiles, the state of the art systems have proven to be efficient in most of the stratosphere and in the lower mesosphere, compared to independent data (Geer et al., 2006). The MOCAGE-PALM system was one of them. In this study, we use a more sophisticated version of this system that benefits of new developments of the assimilation algorithm as described in Sect. 3.

The validation of the LATMOS-IASI data is achieved in this study by performing comparisons over a five-month period (from August to December 2007) between their level 2 ozone data and the ozone fields computed through the com- bined assimilation of SCIAMACHY and MLS ozone data into the MOCAGE-PALM system. In contrast to the usual direct comparison of different data sets, this methodology allows the computation of ozone fields at the time and the location of the observations, within the time and space resolutions of the used CTM. Moreover, the computed ozone field is a good estimate of the true ozone distribution since it results from an assimilation process. Finally, the comparison with the field from the combined assimilation of SCIAMACHY and MLS data is better than a comparison with only one of them, since the combined assimilation gives accurate information trough the whole atmospheric column.

The next sections describe the characteristics of the ozone data used (either assimilated or used for validation), the results from the combined assimilation of SCIAMACHY and MLS ozone data, and the validation of the corresponding analysis ${ }^{1}$. Section 4 focuses on the determination of the error of the LATMOS-IASI ozone data in comparison with ozone analysis obtained from the assimilation of the SCIAMACHY and MLS data sets. Section 5 presents the first results of the assimilation of LATMOS-IASI ozone data within our MOCAGE-PALM system.

\section{Ozone observations}

The ozone data used for this study are either assimilated or used as independent source of information to evaluate outputs from the assimilations process. They come from both spacecraft and in situ instruments.

\subsection{Ozone observations for the assimilations}

\subsubsection{LATMOS-IASI}

A clear-sky retrieval scheme for the near real time inversion of the concentrations of ozone and other trace gases was developed at the LATMOS (Turquety et al., 2004). It includes the inversion module, based on a neural network approach, as well as an error analysis module. The efficiency of the algorithm was demonstrated by its application to the treatment of the atmospheric nadir measurements provided by the Interferometric Monitor for Greenhouse Gases (IMG)/ADEOS (Clerbaux et al., 2003). Applied to the IASI spectra, this algorithm provided data with a maximum sensitivity in the free troposphere (Turquety et al., 2004). The sensitivity extends up in the stratosphere to around $1 \mathrm{hPa}$. In the lower atmosphere the sensitivity is directly linked to thermal contrast (difference between the surface and the atmospheric temperature), as discussed in Clerbaux et al. (2009). When the thermal contrast is large and positive, the measurement is sensitive to the ozone content inside the lower layers. When it is

\footnotetext{
${ }^{1}$ In this paper, an analysis will refer to a four dimensional (3$\mathrm{D}$ in space plus time) field, computed on the model grid, resulting from the assimilation process.
} 
small, the sensitivity in the lowest levels decreases accordingly. Detailed information of the LATMOS-IASI vertical sensitivity is assessed in Boynard et al. (2009).

Global distributions of total ozone column are now routinely extracted from the IASI radiances data at the LATMOS (Clerbaux et al., 2009). Using a perturbation method, the neural network can also provide the averaging kernels associated with the retrievals (Turquety et al., 2004). Unfortunately, as it is time consuming, the present real-time processing of the IASI data does not allow deriving both the columns and the averaging kernels on the global scale. Thus, the IASI total ozone column averaging kernels were not considered in this study. Systematic validations of these total column measurements and profiles retrievals (with averaging kernels), using ground-based and other satellite observations, are provided in Boynard et al. (2009). Preliminary results show that, compared to GOME-2, the LATMOS-IASI data overestimate the ozone total columns by about $6 \%$ at midlatitudes with an excellent correlation of about 0.92 . Over the polar regions and tropics, the correlation is found to be lower and the LATMOS-IASI data still overestimate the ozone content.

The current version of the LATMOS algorithm still encounters problems in case of observations recorded over icy and sandy surfaces. This is due to the lack of available auxiliary data related to surface emissivity and solar reflexion. They should be included in the METOP level 2 products, and should be implemented in the next version of the algorithm. In this paper, we chose not to use the observations recorded over icy and sandy surfaces that represents about $12 \%$ of the overall data set. Both daytime and nighttime measurements are used with a discrimination between them as they have different vertical sensitivities and accuracies.

During the period under study (153 days), there are 12 days without LATMOS-IASI observations due to some MetOp-A calibration operations. Otherwise, an average of about 135000 retrievals of total ozone column are produced per day. With the aim of assimilating these data into a system with a $2^{\circ} \times 2^{\circ}$ global grid, we have to build superobservations since the IASI footprint on the ground is about $12 \mathrm{~km}$ at nadir and 4 measurements are performed at the same time (every $50 \mathrm{~km}$ ). The super-observations are obtained by the computation of the simple mean of all the observations made at the same time (within a minute) in the corresponding $2^{\circ} \times 2^{\circ}$ cell. This procedure reduces the daily number of observations to an averaged value of the order of 21500 .

\subsubsection{TOSOMI SCIAMACHY ozone columns}

SCIAMACHY (SCanning Imaging Absorption spectroMeter for Atmospheric CHartographY) is a scanning spectrometer whose primary objective is to perform global measurements of trace gases in the troposphere and in the stratosphere (Bovensmann et al., 1999). It is designed to measure sunlight transmitted, reflected and scattered by the Earth's atmo- sphere or surface in the ultraviolet, visible and near infrared wavelength region. With its moderate spectral resolution and a wide wavelength range, SCIAMACHY can measure many different trace gases despite their low concentrations. SCIAMACHY has three different viewing geometries: nadir, limb, and sun/moon occultations which yield total column values as well as vertical profiles of trace gases and aerosols in the stratosphere and in the troposphere. SCIAMACHY can observe the whole Earth with a coverage at the equator achieved within 3 days when using only nadir or limb modes.

In this study, we use the ozone columns retrieved from the SCIAMACHY spectra by the TOSOMI algorithm developed at the Royal Dutch Meteorological Institute (KNMI). The retrieval algorithm is an application to SCIAMACHY of the GOME algorithm TOGOMI (Valks and van Oss, 2003). This algorithm is based on the total ozone DOAS (Differential Optical Absorption Spectroscopy) algorithm developed for the OMI instrument (Veefkind et al., 2006). This is suitable as the OMI, SCIAMACHY and GOME instruments are very similar with respect to total ozone column retrieval using the DOAS method. The TOSOMI SCIAMACHY total ozone data (value and error) are available from http://www.temis.nl. They will be further referred as SCIAMACHY data in this paper. Eskes et al. (2005) have presented comparisons between two years of SCIAMACHY data and co-located ground based measurements, and between 6 months of SCIAMACHY data and GOME retrievals. They found that SCIAMACHY ozone columns are, on average, $1.5 \%$ lower than the others data, without any strong dependence on geographical location.

In a similar way to what is done for LATMOS-IASI data, the SCIAMACHY ozone columns have been averaged with a simple mean for the assimilation, on the CTM $2^{\circ}$ by $2^{\circ}$ latitude-longitude grid and are used without taking account of the averaging kernels. During the period under study, there are 3 days without measurements. Otherwise, an average of 25000 aggregated measurements of total ozone column is available each day.

\subsubsection{Aura/MLS ozone profiles}

The Microwave Limb Sounder (MLS) instrument has been flying onboard the Aura satellite in a sun-synchronous polar orbit since August 2004. Vertical profiles of several atmospheric parameters are retrieved from the millimeter and submillimeter thermal emission measured at the atmospheric limb (Waters et al., 2006). Measurements are performed between $82^{\circ} \mathrm{S}$ and $82^{\circ} \mathrm{N}$, with a long-track resolution that varies from about $165 \mathrm{~km}$ to nearly $300 \mathrm{~km}$. For our study we have used the latest version (v2.2) of MLS ozone product. A detailed validation of this product and comparisons with other data sets are available in Froidevaux et al. (2008) and Livesey et al. (2008). They found that in the middle stratosphere, the MLS ozone data have small biases, with a 
random error of the order of 5\%. The error is similar in the upper troposphere and lower stratosphere but can reach $20 \%$ at $215 \mathrm{hPa}$.

The ozone observations assimilated in our study were screened according to their recommendations. We rejected the measurements with odd "Status" fields, with "Quality" fields lower than 1.2, and with "Convergence" fields greater than 1.8. We also restricted the data used to the pressure range from $215 \mathrm{hPa}$ to $0.5 \mathrm{hPa}$, which represents measurements at 16 pressure levels per profile. One interesting feature of MLS is its ability to measure constituents in the Upper Troposphere-Lower Stratosphere (UTLS) where retrievals are made at 4 levels, namely $215 \mathrm{hPa}, 147 \mathrm{hPa}, 100 \mathrm{hPa}$ and $68 \mathrm{hPa}$. Nevertheless, the error is higher in this region with values from $5 \%$ to $100 \%$ below $100 \mathrm{hPa}$, from $2 \%$ to $30 \%$ at $100 \mathrm{hPa}$, while it is below $10 \%$ at lower pressure levels.

The measurement error is also a product of the retrieval algorithm. These errors are used as the standard deviation of the observation error in order to construct the diagonal of the observation error covariance matrix, which is required by the assimilation algorithm. The off-diagonal terms are set to zero. This means that the random observation error of one measurement is assumed to be independent of the random observation error of other measurements along the same profile and the measurements of other profiles. At last, Froidevaux et al. (2008) showed that the averaging kernels' peaks are near unity for the levels we assimilate the data, which means we can use them without specifying the averaging kernels.

For the assimilation, in a manner consistent with the use of the other data sets, we averaged the measurements and their errors that lie at a distance below $2^{\circ}$. The average is a simple mean that does not take into account individual errors. It gives about 2000 measurements per day, and for the period in consideration, there are 16 days without Aura/MLS measurements.

\subsection{Ozone observations for evaluation of the analyses}

\subsubsection{OMI-DOAS total ozone columns}

Also onboard Aura, the Ozone Monitoring Instrument (OMI) is a nadir viewing imaging spectrograph that measures the solar radiation backscattered by the Earth's atmosphere and surface (Levelt et al., 2006). OMI combines the advantages of European ESA instruments GOME and SCIAMACHY with the characteristics of the NASA's TOMS instrument, that measures the complete spectrum in the ultraviolet/visible wavelength range with a very high spatial resolution and a daily global coverage. During one Aura orbit, OMI performs approximately 1650 measurements on the sunlit portion of the Earth. In the standard global observation mode, 60 across track ground pixels are measured simultaneously, the pixel size being $13 \mathrm{~km} \times 24 \mathrm{~km}$. These measurements cover a swath of approximately $2600 \mathrm{~km}$ wide on the surface, which enables measurements with a daily global coverage.

In this study, we use the OMI total ozone columns (data available from http://www.temis.nl) produced with the KNMI DOAS method (Veefkind et al., 2006). The OMIDOAS total ozone columns have showed a globally averaged agreement better than $2 \%$ with the ground-based observations (Balis et al., 2007). The data shows no significant dependence on latitude except for the high latitudes of the Southern Hemisphere ( $\mathrm{SH})$ where it systematically overestimates the total ozone value by $3 \%$ to $5 \%$.

\subsubsection{Ozone sondes}

Ozone soundings were obtained from the World Ozone and Ultraviolet Radiation Data Centre (WOUDC, http:// www.woudc.org/) and the Southern Hemisphere Additional Ozonesondes project (SHADOZ, http://croc.gsfc.nasa.gov/ shadoz, Thompson et al., 2003). In this study, we use data from 23 locations mainly located in the latitude band from $30^{\circ} \mathrm{S}$ to $60^{\circ} \mathrm{N}$ (Fig. 1). Most of the stations are equipped with Electrochemical Concentration Cell (ECC) sondes. Four of them are equipped with Carbon-Iodide sondes and one with Brewer-Mast sondes.

As stressed by Geer et al. (2006), even if this data set may be somewhat heterogeneous, this heterogeneity is acceptable in order to obtain a wider coverage. According to laboratory comparisons of the three sonde types (Smit et al., 1998), the random variability of the overall data is estimated at about 10 to $15 \%$ in the UTLS and near 5\% in the middle stratosphere where ozone concentrations are maximums.

\section{Production of the ozone analysis}

One aim of this paper is first to compare LATMOS-IASI total ozone column with data sets from other instruments. The way we perform this comparison is similar to what was completed in Massart et al. (2007). The LATMOS-IASI total ozone columns are compared to the columns computed from an ozone analysis. The analysis is obtained from the combined assimilation of MLS and SCIAMACHY data into the MOCAGE-PALM system. The next sections describe the assimilation system and the resulting the ozone analysis obtained for the five last months of 2007.

\subsection{Assimilation system}

The assimilation system is similar to the one used in Massart et al. (2007). It is based on the MOCAGE-PALM system developed jointly by CERFACS and Météo-France in the framework of the FP5 European project ASSET (Lahoz et al., 2007b) and then extended with the support of the Ether centre for atmospheric chemistry products and services. The assimilation algorithm is a 3D-VAR, in the FGAT (first guess at appropriate time) variant (Fisher and Anderson, 2001). The 


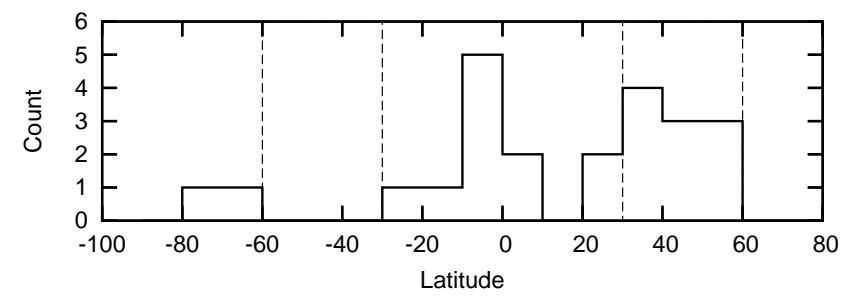

Fig. 1. Number of ozonesonde stations used for validation, by latitude (in $10^{\circ}$ bins).

system is based on the Météo-France comprehensive threedimensional chemistry transport model (CTM) MOCAGE and the CERFACS PALM software (Buis et al., 2006). The CTM MOCAGE covers the planetary boundary layer, the free troposphere and the stratosphere. It provides a number of optional configurations with varying domain geometries and resolutions, as well as chemical and physical parameterization packages. MOCAGE is currently used for several applications, with recent examples in chemical weather forecasting (Dufour et al., 2004), chemistry-climate interactions (Teyssèdre et al., 2007) and intercontinental transport of ozone and of its precursors (Bousserez et al., 2007).

The first version of the MOCAGE-PALM assimilation system (Massart et al., 2005a,b), as it was originally implemented for the ASSET project, provided good quality ozone fields compared with ozonesondes and UARS/HALOE measurements with errors of the same order as those produced by several other assimilation systems (Geer et al., 2006). In order to improve our assimilation system, several changes have been recently made on the model resolution and on the characterization of the forecast error (Massart et al., 2007; Pannekoucke and Massart, 2008).

In this study, the domain geometry and resolution cover a global $2^{\circ}$ by $2^{\circ}$ horizontal grid with 60 level vertical levels from the surface up to $0.1 \mathrm{hPa}$. The meteorological forcing fields are provided by the operational European Centre for Medium-Range Weather Forecasts (ECMWF) numerical weather prediction model. For computing the ozone chemical fields, we adopted the linear ozone parameterization developed by Cariolle and Teyssèdre (2007) in its latest version 2. It is based on the linearization of ozone production/destruction rates using an altitude/latitude chemical model. So in the troposphere the model does not account for local ozone productions due to precursor emissions (e.g. $\mathrm{NO}_{\mathrm{x}}$ emissions). Therefore we expect the ozone parameterization to have limitations in the boundary layers. In the free troposphere and the stratosphere the parameterization performs with accuracies similar to full chemical models (Geer et al., 2007).

The forecast error covariance matrix of the MOCAGEPALM assimilation system is split into a correlation matrix and a diagonal matrix filled with the forecast error variance (square of the forecast error standard deviation). The correlation matrix is divided into a horizontal and a vertical operator, both modelled using a diffusion equation (Weaver and Courtier, 2001). A preliminary work based on an ensemble of assimilation runs allowed us to estimate the different length-scales of the forecast error correlation functions (assumed to have a Gaussian shape). The length-scales were found strongly inhomogeneous in time and space with values ranging from $100 \mathrm{~km}$ to $300 \mathrm{~km}$ in the meridional direction, and from $100 \mathrm{~km}$ to $600 \mathrm{~km}$ for the zonal ones. However, the assimilation system is based on a homogeneous horizontal length-scale. Therefore, the horizontal correlation of the forecast error is computed with a trade-off value for the homogeneous length-scale of $220 \mathrm{~km}$ (that corresponds to a distance of $2^{\circ}$ at the equator).

The vertical correlation is computed with a space dependent dimensionless length-scale $L$. The correlation $\mu_{i j}$ between two pressure levels $i$ and $j$ is expressed as a locally Gaussian function of the logarithm of their pressure ratio $\left(p_{i} / p_{j}\right)$ and a local length-scale $L_{i j}$,

$\mu_{i j}=\exp \left[-\frac{1}{L_{i j}^{2}} \cdot \log ^{2}\left(\frac{p_{i}}{p_{j}}\right)\right]$.

In order to increase the consistency of our analysis, we added several diagnostics as discussed by Desroziers et al. (2005). Based on the combinations of assimilated observations minus background, assimilated observations minus analysis, and background minus analysis, they provide a set of consistency checks of an assimilation experiment. In our case, these diagnostics are used to compute two multiplicative correction coefficients $s_{b}$ and $s_{o}$. The first one is applied to $\mathbf{B}$, the covariance matrix of the forecast error, so that the assimilation is performed with $s_{b}^{2} \mathbf{B}$. The second coefficient is applied on $\mathbf{R}$, the covariance matrix of the observation error, so that the assimilation is performed with $s_{o}^{2} \mathbf{R}$. In theory, these coefficients are suitable for the assimilation period during which they are computed. In practice, they are computed over a daily period divided into 8 assimilation windows and are used for the next day. This procedure can be adopted due to the slow variation found in the standard deviation of the forecast and observation errors.

\subsection{Numerical experiment}

The period under study spans from first of August to the end of December 2007. Initial global ozone concentrations for 1 July 2007 were built from a July climatological ozone. A 15 days assimilation of MLS data from this initial state was performed to obtain coherent ozone concentrations for 15 July 2007. All the assimilation experiments start from this date. The computation of the diagnostics for the intercomparisons begins 1 August 2007 so that the fields have little-dependence on the initial condition. A simulation of MOCAGE in the free mode (without any assimilation) 

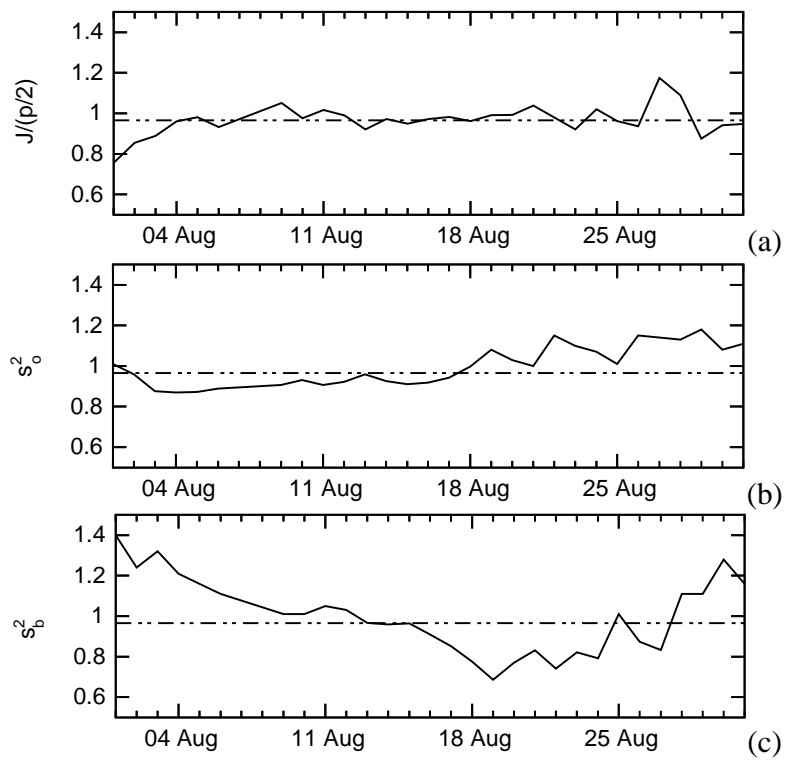

Fig. 2. Diagnostics of the SCIAMACHY assimilation for August 2007. (a) Values of the cost function at the minimum divided by the half number of observations. Values of the diagnosed (b) observation and (c) forecast error correction coefficients.

starting on 15 July 2007 is also performed in order to produce a reference from which the impact of the assimilation is evaluated.

We assimilate the combined information from MLS and SCIAMACHY measurements. The major advantage in this combined assimilation is that the MLS data give constrains to the computed ozone profiles in the stratosphere and in the upper troposphere, whereas the SCIAMACHY data brings information on the integrated ozone columns. Before combining the two data sets, it is important to ensure coherence between these two sources of information. This is achieved by comparing the analyses of the two single instrument assimilation experiments of the two types of ozone measurements.

\subsection{Separate MLS and SCIAMACHY assimilations}

We first assimilated MLS and SCIAMACHY data in two separated experiments. For these experiments, the dimensionless length-scale used for the vertical correlation model of the forecast error is set to a value of 0.35 . The standard deviation of the background error is prescribed as a percentage of the ozone concentration, with a proportionality coefficient adjusted using the previously described a posteriori diagnostics. As illustrated in Fig. 2, the tuning of the correction coefficients for the standard deviation of the forecast and the observation errors, insures a good consistency of the assimilation system. All along the assimilation period, the minimum of the cost function remains close to half the number of

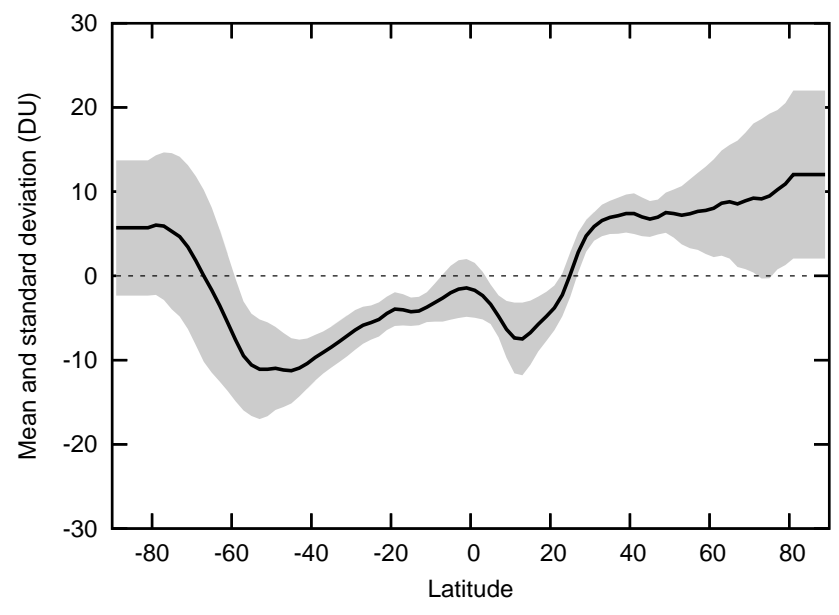

Fig. 3. Average difference (in DU) between the total ozone columns from the SCIAMACHY analysis minus the total ozone columns from the MLS analysis (black line) for the period 1 August to 31 December 2007. The shaded area represents the average plus and minus the standard deviation of the difference for the same period.

observations. On average, the resulting observation error is approximately the same as the one specified in the data. The standard deviation of the forecast error is about $15 \%$ of the ozone concentration for the MLS assimilation, and $2 \%$ for the SCIAMACHY assimilation.

Even if the MLS data only provides ozone profiles, the total ozone columns computed from the MLS analysis, account for the information brought by the instrument. Therefore the total ozone columns computed from the MLS analysis and those computed from SCIAMACHY analysis can be legitimately compared. We computed for the whole period, the average and the standard deviation of the difference between the analysed SCIAMACHY total ozone columns and the analysed MLS ones. MLS having no measurements beyond $82^{\circ} \mathrm{S}$ and beyond $82^{\circ} \mathrm{N}$, we assumed that the difference in this polar regions is constant and equal to the one computed on $82^{\circ} \mathrm{S}$ and on $82^{\circ} \mathrm{N}$ for, respectively the Southern and Northern polar regions. Figure 3 shows that there is a good consistency between the two sources of information, the averaged difference being mostly below 10 Dobson Unit (DU) in absolute value. The variation of the difference from one month to another is also below $10 \mathrm{DU}$. In the region between about $60^{\circ} \mathrm{S}$ and $20^{\circ} \mathrm{N}$, for all months from August to December, the total ozone columns from SCIAMACHY analysis are lower than those from the MLS analysis, with little variations from one month to another. The monthly averaged differences are nearly systematically positives in the polar regions, with the SCIAMACHY analysis being larger than the MLS one. In the Southern Polar Region (SPR), the differences are larger for the three first months (August to October), while the maximum differences are found from October to November over the Northern Polar Region (NPR). 
The differences between the two analyses are of the order of the contribution of the tropospheric fraction to the total ozone column. Since the assimilation of the MLS data does not strongly constrain the tropospheric ozone concentrations, the difference can arise from a tropospheric bias in the model as well as a bias in the MLS or SCIAMACHY data. It may also results from the error introduced while neglecting the SCIAMACHY averaging kernels.

Before performing a combined assimilation, we removed the difference between the two data sets. Changing the tropospheric parameterization of the model in order to have coherent data sets, proved to be more complex than modifying the data values. We decided to modify the SCIAMACHY data rather than the MLS one because we could otherwise introduce new error sources when projecting a total column difference back to a vertical profile. In addition, we give a less confidence to the SCIAMACHY data because we do not use the associated averaging kernels. Consequently, for each month, the differences between the SCIAMACHY and the MLS total ozone column analyses were averaged in time and longitude. Then, the SCIAMACHY data were corrected by subtracting the monthly latitude dependent difference.

In addition, since the diagnosed SCIAMACHY and MLS observation errors were of the same magnitude than the specified instrumental errors, we combined the MLS data and the corrected SCIAMACHY data without any change to the specified instrumental errors.

\subsection{Forecast error parameterisation}

In order to improve the quality of our combined analysis, we used a more efficient parameterisation of the forecast error. In our previous works, we assumed that the standard deviation of the forecast error is proportional to the ozone concentration, and that the length-scale for the vertical correlation of the forecast error is constant. In this study, following the work we carried out in Pannekoucke and Massart (2008), we determined the standard deviation and the length-scale using an ensemble of assimilation runs that has previously proved to be efficient in the meteorological forecast framework (Belo Pereira and Berre, 2006). The method consists on the construction of an ensemble of realizations of the random forecast error starting from the output of an ensemble of assimilation runs. Statistical calculations on the ensemble of realizations allow the estimation of the standard deviation and the correlation length-scales of the forecast error. To build the ensemble, five sets of perturbed data are obtained using a random generation. For each observation of the reference data set, five observations are generated by a Gaussian random noise with a mean equal to the value of the reference observation and a standard deviation equal to the observation error. The monthly statistics are hence computed using four forecasts per day, given an ensemble of about 600 realizations for each 30 days period. As each assimilation run is performed with the same dynamics and chemistry, the com-

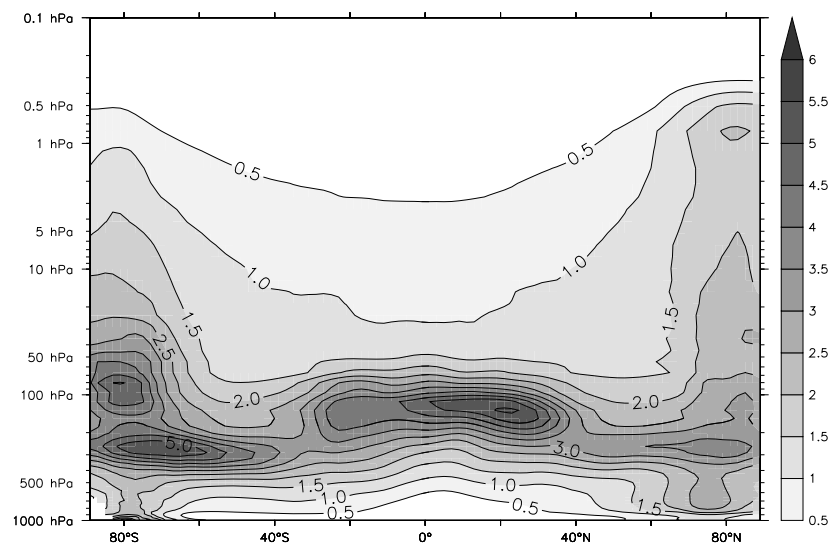

Fig. 4. Zonal average of the August to December 2007 diagnosed ozone forecast error standard deviation (in \%) as a function of pressure. The diagnostic is obtained from an ensemble of perturbed combined assimilations of MLS and SCIAMACHY data.

puted statistics are an underestimation of the true ones. But for the standard deviation, we expect that its shape is correct while its amplitude is adjusted using the previously describes corrective coefficient $s_{b}$. To get a more precise estimation, one can use for each run a perturbed dynamics according to its own error. But such perturbation in the dynamical fields are difficult to build.

Figure 4 illustrates the standard deviation of the forecast error diagnosed for the whole period. It shows that on average the standard deviation is higher in the UTLS region with values between 3\% and 5\%. Below, in the troposphere, the standard deviation is higher over the polar regions than over the other regions of the globe. It is higher over the NPR in August and September, and higher over the SPR in December (figure not shown). In the middle stratosphere, the standard deviation is higher over the NPR at the end of the period while it is higher over the SPR in August. In the upper stratosphere, the standard deviation is rather homogeneous. So, the assimilation process gives more confidence to the observations in the UTLS and in the polar regions.

Figure 5 shows the length-scale of the vertical correlation of the forecast error diagnosed for the entire period. The length-scale is nearly constant in the middle stratosphere, increases in the UTLS region, and decreases in the troposphere. In the upper stratosphere and mesosphere, it increases up to $0.5 \mathrm{hPa}$ and decreases above that level (probably due to the top boundary effects). In terms of data assimilation, the information brought by an observation is spread over a larger vertical range if the length-scale is higher. So, the spread is more important in the upper stratosphere above $10 \mathrm{hPa}$, and in the troposphere but to a lower extent.

The seasonal and regional variability of the length-scale is higher in the upper stratosphere and mesosphere (see the shaded area in Fig. 5). Since our objective is mainly focused 


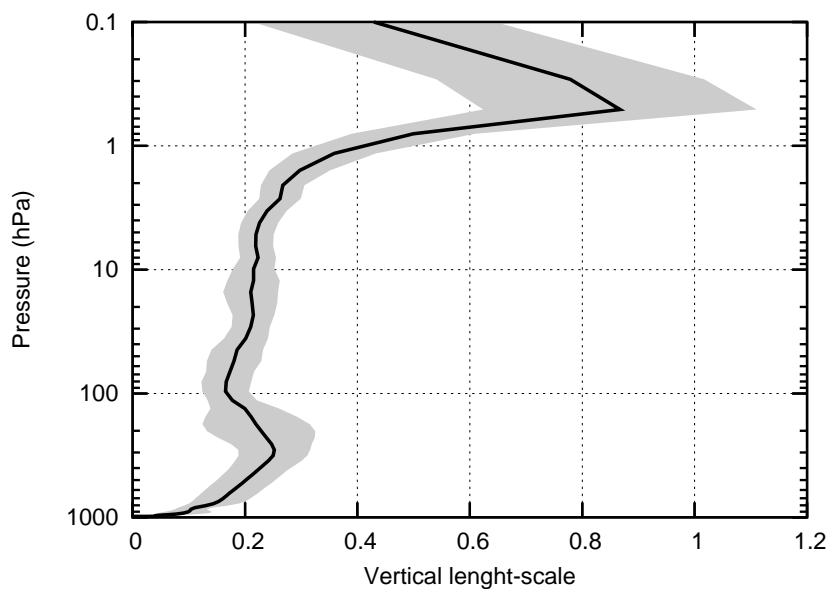

Fig. 5. Global average of the August to December 2007 diagnosed dimensionless length-scale of the vertical forecast correlation error, as a function of pressure. The diagnostic is obtained from an ensemble of perturbed combined assimilations of MLS and SCIAMACHY data. The shaded area represents the length-scale plus and minus its standard deviation calculated over the same period.

on tropospheric and stratospheric ozone, the optimization of our system in the upper stratosphere and mesosphere is not crucial. In consequence, we adopted a vertical varying length-scale that is the same for the whole globe. This choice allows a significant reduction of the numerical cost of the parameterisation.

\section{Validation of the ozone analyses}

The ozone analysis obtained by the combined assimilation of MLS and SCIAMACHY data as described previously, must be compared to independent data. The benefit brought by the assimilation is evaluated in comparison to the free simulation of MOCAGE. Since ozone total columns and profiles are assimilated, the evaluation is carried out by comparison with profiles from ozonesondes, and with total ozone columns from OMI-DOAS.

\subsection{Comparison with ozonesondes}

To compare ozonesonde measurements with the free model simulation and with the MLS plus SCIAMACHY analysis fields, all the observed profiles have been interpolated on a common vertical pressure grid. Then, for each interpolated observed profile, the co-located (in space and time) model profile is computed using the nearest neighbour for the spatial interpolation and a linear time interpolation. Following Geer et al. (2006), the difference in the vertical profiles is normalized by a combination of the Logan (1999) tropospheric climatology with the Fortuin and Kelder (1998) stratospheric climatology. The average and standard deviation of the normalized differences, expressed as percentages,
Table 1. Number of ozonesonde profiles used over the period August to December 2007 as a function of latitude band.

\begin{tabular}{ccc}
\hline $90^{\circ} \mathrm{S}-60^{\circ} \mathrm{S}$ & $30^{\circ} \mathrm{S}-30^{\circ} \mathrm{N}$ & $30^{\circ} \mathrm{N}-60^{\circ} \mathrm{N}$ \\
\hline 62 & 133 & 233 \\
\hline
\end{tabular}

are then computed over the globe and aggregated over latitude bands of 30 degrees, except for the equatorial region where they are averaged over a larger band of 60 degrees. The results are analysed only between the surface and the $5 \mathrm{hPa}$ level since ozonesondes have large errors above that level. Unfortunately, for the period under study, ozonesondings were unavailable for the two latitude bands $\left[60^{\circ} \mathrm{S}-\right.$ $\left.30^{\circ} \mathrm{S}\right]$ and $\left[60^{\circ} \mathrm{N}-90^{\circ} \mathrm{N}\right]$. The number of ozonesonde profiles per latitude band used for the validation on the ozone analyses is given in Table 1 .

Figure 6 shows the average difference between ozonesondes and the free simulation, and between ozonesondes and the combined MLS and SCIAMACHY analysis. It appears that the free simulation has a global bias below $20 \%$ in absolute value, with an overestimation of the ozone concentrations in the stratosphere, and an underestimation in the troposphere. The largest ozone overestimation is found in the SPR, between $250 \mathrm{hPa}$ and $50 \mathrm{hPa}$. This overestimation is maximum around $150 \mathrm{hPa}$, and is more pronounced in November and December at the end of the ozone depletion period and the beginning of the ozone recovery (figure not shown). The model also overestimates the ozone by about $20 \%$, each month, in the $30^{\circ} \mathrm{N}-60^{\circ} \mathrm{N}$ region between $100 \mathrm{hPa}$ and $10 \mathrm{hPa}$. This apparent accumulation of ozone over the polar regions with the free simulation can be related to a too efficient equator to pole meridional circulation in the forcings of the model. Such a bias in the ECMWF wind analyses that force the CTM has been identified by MongeSanz et al. (2007) and Cariolle and Teyssèdre (2007). In the Equatorial region, the free model simulation tends to underestimate ozone particularly in the mid and upper troposphere (below $100 \mathrm{hPa}$ ). This results from the overestimation of the vertical wind velocities associated with the meridional circulation bias.

The tropospheric biases showed by Fig. 6 are not coherent with the difference between the total ozone column obtained with the MLS and the SCIAMACHY analyses. Assuming that the assimilation of the MLS data constrains mainly the stratosphere without bias, the MLS analysis would underestimates the total ozone in the equatorial region and overestimates it in the SPR. However, Fig. 3 shows the opposite. As a consequence, the difference between the SCIAMACHY analysis and the MLS analysis is not dominated by the tropospheric biases in the model. But, it could come from biases in the data or most probably by the fact that the SCIAMACHY averaging kernels were neglected. 
(a) Global (428 obs.)

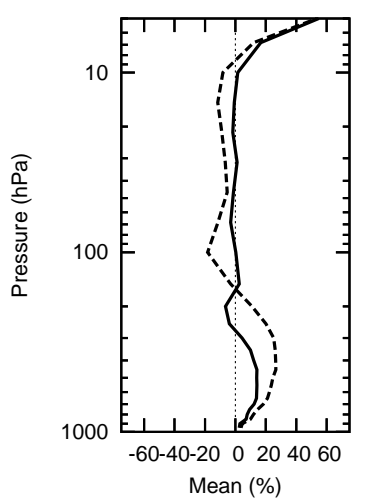

(c) $30 \mathrm{~S}$ to $30 \mathrm{~N}$ (133 obs.)

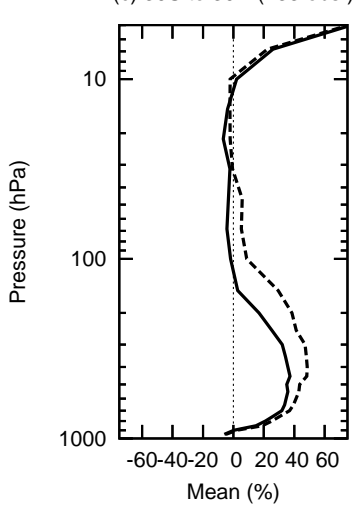

(b) $90 \mathrm{~S}$ to $60 \mathrm{~S}$ (62 obs.)

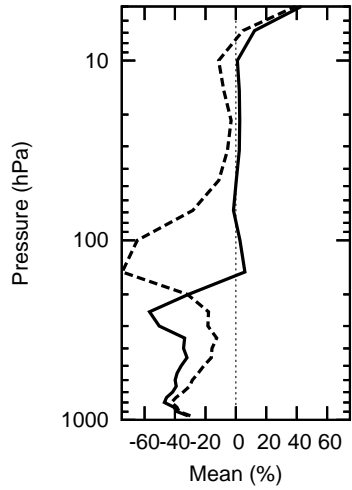

(d) $30 \mathrm{~N}$ to $60 \mathrm{~N}$ (233 obs.)

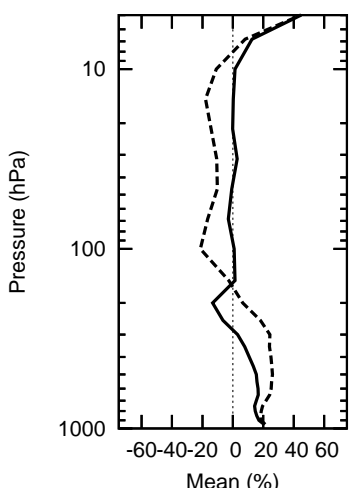

Fig. 6. Mean of [ozonesondes - analysis] (black line) and [ozonesondes - free simulation] (dotted line) ozone profiles, normalised by climatology, for the period 1 August to 31 December 2007. The latitude band limits and the number of ozonesonde profiles used are given in the title of each sub-plot.

The combined assimilation of MLS and SCIAMACHY reduces the biases. In particular, in the stratosphere, between $150 \mathrm{hPa}$ and $10 \mathrm{hPa}$, the difference between ozonesondes and the analysis is below 3\% in absolute value. In the upper stratosphere above $10 \mathrm{hPa}$, since the standard deviation of the forecast error is low, observations have a smaller weight and the analysis remains close to the free simulation. In the UTLS, the standard deviation of the forecast error is larger and the analysis is driven towards the MLS data. Jiang et al. (2007) reported that, compared to the ozonesondes, MLS products overestimate ozone at $215 \mathrm{hPa}$ by about $20 \%$ at middle and high latitudes. Similarly, the assimilation of MLS data produces an ozone overestimation at this altitude range, especially over the SPR. Elsewhere in the UTLS and in the mid-troposphere, the information brought by the data is vertically spread and the biases are reduced.

Figure 7 shows the standard deviation of the difference between ozonesondes and the free simulation and between ozonesondes and the MLS plus SCIAMACHY analysis for the period under study. It appears that the random error between the model without assimilation and the ozonesondes is globally below $20 \%$ between $10 \mathrm{hPa}$ and $100 \mathrm{hPa}$. This value (a) Global (428 obs.)

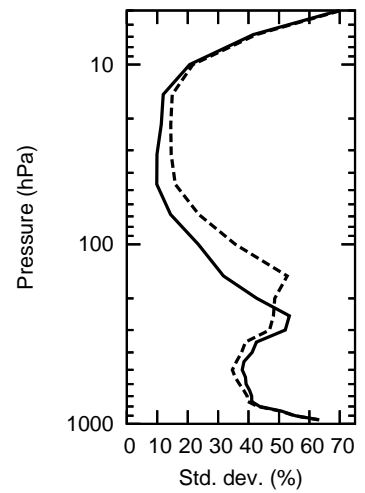

(c) $30 \mathrm{~S}$ to $30 \mathrm{~N}$ (133 obs.)

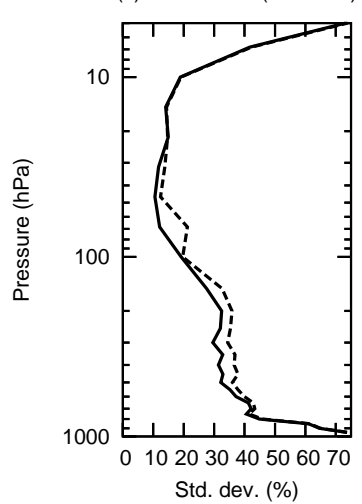

(b) $90 \mathrm{~S}$ to $60 \mathrm{~S}$ (62 obs.)

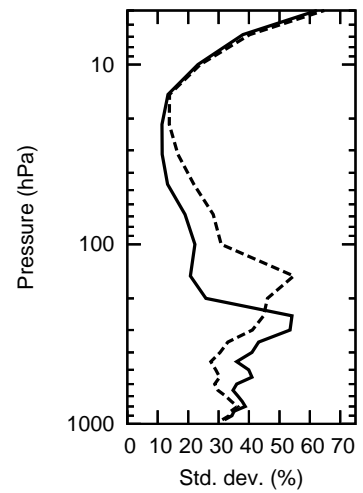

(d) $30 \mathrm{~N}$ to $60 \mathrm{~N}(233 \mathrm{obs}$.)

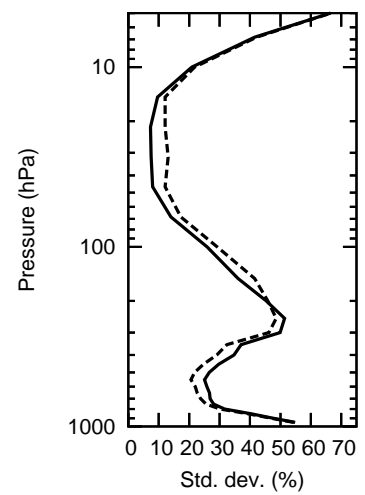

Fig. 7. Same as Fig. 6 for the standard deviation.

is of the same magnitude as the measurement error. The error grows below $100 \mathrm{hPa}$ and reaches about $50 \%$ at $250 \mathrm{hPa}$. The error is nearly the same for all latitudes, except over the SPR with slightly higher values, with no significant variations from one month to another. Analysis reduces the standard deviation. However, the reduction occurs mainly in the SPR between $200 \mathrm{hPa}$ and $15 \mathrm{hPa}$. In particular, at $150 \mathrm{hPa}$ the standard deviation decreases from $54 \%$ for the free simulation to $20 \%$ for the analysis. In other regions, the reduction covers mainly the $200 \mathrm{hPa}$ to $15 \mathrm{hPa}$ altitude range. A small increase of the standard deviation can be noticed in the troposphere.

\subsection{Comparison with OMI-DOAS}

The daily total ozone columns from OMI-DOAS were averaged on the $2^{\circ}$ by $2^{\circ}$ MOCAGE horizontal grid. Moreover, all the measurements are assumed to be made at 12 UTC and the real measurement time is neglected. The difference between this averaged OMI-DOAS data and the free simulation or the analysis, normalized by the OMI-DOAS ones, is then computed each day at 12 UTC, which means that the comparison is not done at the observation time. Figure 8 shows the zonal average and the standard deviation of this difference. 
(a)

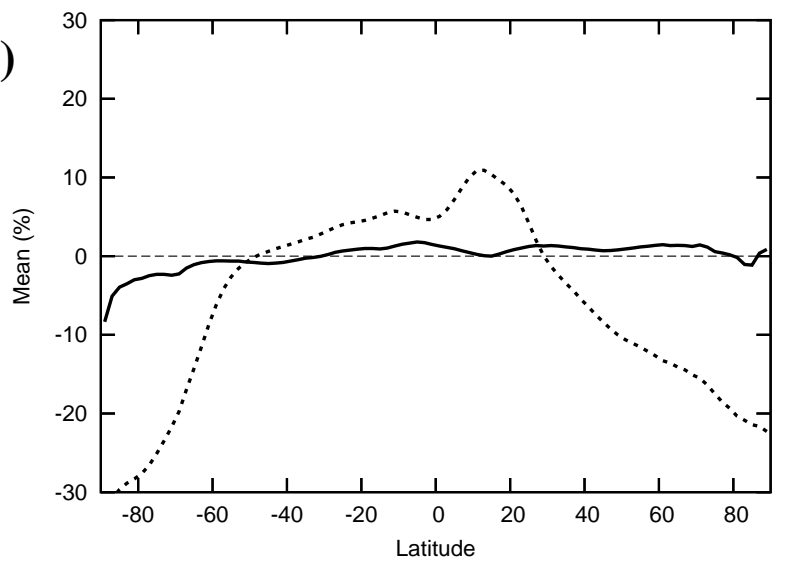

(b)

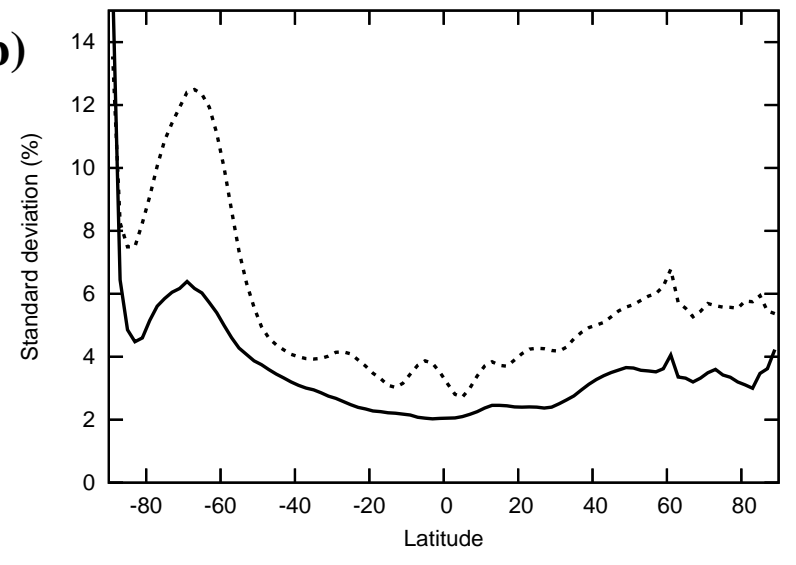

Fig. 8. (a) Mean and (b) standard deviation of (OMI-DOASsimulation)/OMI-DOAS total ozone column. All the plots are drawn for the period 1 August to 31 December 2007. The dotted line represents the free simulation, the black line represents the combined MLS and SCIAMACHY ozone analysis.

The first panel of Fig. 8 shows that the free simulation has an important bias in terms of total ozone columns compared to OMI-DOAS ones. The free simulation systematically overestimates the total ozone columns in the polar regions by $20 \%$ to $30 \%$. This is consistent with the previous comparison with ozonesondes and it is related to the intensity of the meridional circulation. So, the biases of the free simulation are minimum at mid-latitudes, and increase again at low latitudes where the free simulation systematically underestimates the total ozone columns by $5 \%$ to $10 \%$. This bias shows little variations from one month to another. The maximum value of $16.5 \%$ is reached in the middle of October around $10^{\circ} \mathrm{N}$. In the SPR, the bias is lower in December, while it is lower in August over the NPR. The maximum biases are reached in the mid-September for the NPR with about $-30 \%$, and in the middle of November for the SPR with about $-65 \%$.
The computed total ozone columns from the analysis of the combined MLS and SCIAMACHY data agree well with the OMI-DOAS measurements. This is consistent with the low biased of the analysis compared to the ozonesondes in the altitude range where the largest fraction of the stratospheric ozone lies. Figure 8 shows that the analysis underestimates by less than $1.5 \%$ the total ozone columns between $30^{\circ} \mathrm{S}$ and $80^{\circ}$. It also shows that over the SPR, the analysis overestimates the ozone content by $3 \%$ to $8 \%$ with the largest contribution for the November month.

The lower panel of Fig. 8 shows that the free simulation produces total ozone columns that deviate by $3 \%$ to $6 \%$ from the OMI-DOAS ones at most latitudes. The error is however the largest between $50^{\circ} \mathrm{S}$ and the South Pole. It peaks to $12.5 \%$ at $67^{\circ} \mathrm{S}$. This error peak is present all over the period under study, with a maximum in September. Its location corresponds to the edges of the ozone hole, where ozone meridional gradients are maximums. The model error could come from a difficulty with the free simulation to locate the vortex edges with a sufficient accuracy. It could also come from the fact that the comparison is not done at the exact observation time and the dynamical situation changes rapidly within a day in this region.

Figure $8 \mathrm{~b}$ indicates that the standard deviation of the analysis is reduced compared to the free simulation. It lies between 2 and $4 \%$ in most regions and represents an important improvement compared to the free simulation. In particular, the standard deviation computed with the analysis around $67^{\circ} \mathrm{S}$ is significantly reduced by a factor 2 . The analysis reduces substantially the uncertainties around the edges of the Antarctic vortex. Nevertheless, the error is higher than in most of the other regions. This is probably the result of the comparison which does not consider the time-shift of the analysis with the observations. At least, inside the Southern Polar vortex, there is no significant improvement in the statistics, especially for the month of November.

\subsection{Synthesis on the MLS plus SCIAMACHY analysis}

The combined assimilation of MLS and SCIAMACHY data provides ozone concentrations in a good agreement with the independent ozonesondes measurements mainly in the stratosphere (with a difference below 3\%). As for the analysed total ozone columns, they are slightly biased (predominantly below $1.5 \%$ ) compared to the independent OMIDOAS data.

In terms of random variability, the difference between the analysis and the ozonesondes is lower than $20 \%$. Assuming that this error is the sum of the analysis error and the ozonesondes error, with an instrument accuracy around $5 \%$ to $15 \%$ the random variability of our analysis is about $10 \%$ for the ozone concentrations. Concerning the total ozone columns, the difference between the analysis and the OMI-DOAS data are mainly below $4 \%$, the instrumental error being around $2 \%$. With the same assumptions on the error 
summation, the random variability of our analysis is below $2 \%$ for the total ozone columns. Notwithstanding, the errors are higher at the edges of the Antarctic vortex and over the South Pole in November.

\section{Assimilation of the LATMOS-IASI ozone data}

The previous section showed that our ozone analysis provides a satisfying four dimensional (3-D in space plus time) representation of the true distribution with low systematic and random errors. It is thus pertinent to first compare the LATMOS-IASI data to these quality ozone fields before any attempt of assimilation.

\subsection{Methodology}

The comparison between the reference (not spatially averaged) LATMOS-IASI ozone data $\boldsymbol{y}_{\text {iasi }}^{o}$ and the combined MLS and SCIAMACHY analysis $\boldsymbol{x}_{m+s}^{a}$ is performed at the LATMOS-IASI time and space resolution. For each LATMOS-IASI data, we compute the co-located (in space and time) analysis using an observation operator $\mathbf{H}$ that is the combination of a vertical integration (in order to compute a single column) with a bi-linear spatial interpolation and a linear time interpolation between two successive analysed fields separated by $3 \mathrm{~h}$. Afterwards, the difference between the LATMOS-IASI data and the co-located analysis, further referred as departure, is computed. This departure is then projected on the $2^{\circ}$ by $2^{\circ}$ horizontal model grid. Doing so, we obtained in each cell of the mesh, an ensemble of differences between LATMOS-IASI measurements and the co-located analysis. Figure 9 shows the repartition of the number of these departures per cell over the globe. This number varies from 200 to 3000 except in regions where the LATMOS-IASI data has been discarded due to insufficient knowledge of the emissivity properties of the ground. The distribution between daytime and nighttime measurements is similar except over the NPR where the number of nighttime measurements can be $40 \%$ higher than the daytime ones.

For each cell, we computed the average and the variance of the ensemble of the departures. The average represents the systematic error in terms of total column ozone between the LATMOS-IASI measurements and the combined MLS and SCIAMACHY analysis. To ensure coherence between the data and the model, this error has to be removed before assimilating LATMOS-IASI measurements. The variance of the departures gives information on the variance of the observation error. The departure is expressed as

$\boldsymbol{y}_{\text {iasi }}^{o}-\mathbf{H} \boldsymbol{x}_{m+s}^{a}=\boldsymbol{y}_{\text {iasi }}^{o}-\mathbf{H} \boldsymbol{x}^{t}-\mathbf{H}\left(\boldsymbol{x}_{m+s}^{a}-\boldsymbol{x}^{t}\right)$,

where $\boldsymbol{x}^{t}$ represents the true unknown ozone concentration and the linear observation operator $\mathbf{H}$ is expressed as a matrix.

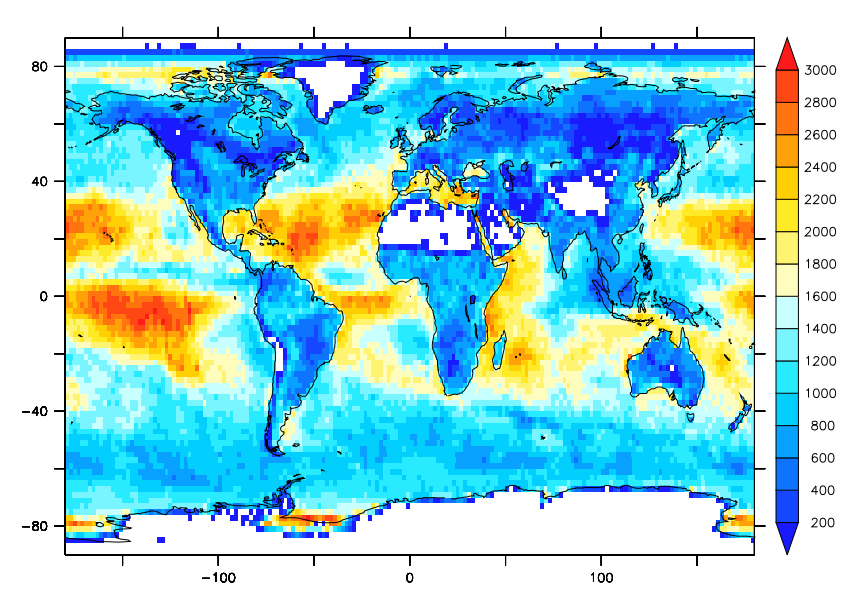

Fig. 9. Number of LATMOS-IASI measurements computed on $2^{\circ}$ by $2^{\circ}$ cells, for the period 1 August to 31 December 2007 .

As the LATMOS-IASI observation error $\boldsymbol{y}_{\text {iasi }}^{o}-\mathbf{H} \boldsymbol{x}^{t}$ and the MLS and SCIAMACHY analysis error $\boldsymbol{x}_{m+s}^{a}-\boldsymbol{x}^{t}$ are independent, the variance (denoted var $[\cdot]$ ) of the departure is given by the sum of the two variances,

$$
\begin{aligned}
\operatorname{var}\left[\boldsymbol{y}_{\text {iasi }}^{o}-\mathbf{H} \boldsymbol{x}_{m+s}^{a}\right] & =\operatorname{var}\left[\boldsymbol{y}_{\text {iasi }}^{o}-\mathbf{H} \boldsymbol{x}^{t}\right] \\
& +\mathbf{H} \operatorname{var}\left[\left(\boldsymbol{x}_{m+s}^{a}-\boldsymbol{x}^{t}\right)\right] \mathbf{H}^{T},
\end{aligned}
$$

where $\mathbf{H}^{T}$ is the transpose of the linear observation operator H.

Then, the variance of the LATMOS-IASI observation error can be expressed as the difference between the variance of the departure and the variance of the MLS and SCIAMACHY analysis error (projected into the observation space),

$$
\begin{aligned}
\operatorname{var}\left[\boldsymbol{y}_{\text {iasi }}^{o}-\mathbf{H} \boldsymbol{x}^{t}\right] & =\operatorname{var}\left[\boldsymbol{y}_{\text {iasi }}^{o}-\mathbf{H} \boldsymbol{x}_{m+s}^{a}\right] \\
& -\mathbf{H} \operatorname{var}\left[\left(\boldsymbol{x}_{m+s}^{a}-\boldsymbol{x}^{t}\right)\right] \mathbf{H}^{T} .
\end{aligned}
$$

In order to estimate the variance of the LATMOS-IASI observation error, we estimated the variance of the MLS plus SCIAMACHY analysis error in a similar way to the estimation of the variance of the forecast error, using the ensemble of perturbed observations previously described. We found that the standard deviation of the analysis error is of $0.5 \%$ at the equator and increases to $1 \%$ at the Pole. This result is consistent with the previous evaluation of an error of about $2 \%$ obtained by the comparison between the MLS plus SCIAMACHY analysis and the OMI-DOAS data. Consequently, we can assume that the variance of the forecast error is negligible compared to the variance of the LATMOSIASI observation error. The variance of the LATMOS-IASI observation error is then simply obtained by computing the variance of the ensemble of departures.

To measure the benefit of assimilating LATMOS-IASI data instead of SCIAMACHY data, we can compare the 
mean and the standard deviation of the differences between the two analyses (MLS plus SCIAMACHY in one hand and MLS plus LATMOS-IASI in another hand) and the soundings or the OMI-DOAS measurements. Considering that the subscript $m+i$ refers to the combined assimilation of MLS and LATMOS-IASI, we compute $\boldsymbol{d}_{m+i}^{a}$ and $\boldsymbol{d}_{m+s}^{a}$, where $\boldsymbol{d}^{a}$ is the departure of the analysis,

$\boldsymbol{d}^{a}=\boldsymbol{y}^{o}-\mathbf{H} \boldsymbol{x}^{a}$,

with $\boldsymbol{y}^{o}$ representing either OMI-DOAS or ozonesondes data and $\mathbf{H}$ the corresponding observation operator.

The mean $E\left[\boldsymbol{d}^{a}\right]$ and the standard deviation $\operatorname{Std}\left[\boldsymbol{d}^{a}\right]$ of these departures can next be computed. Finally, a gain $\boldsymbol{g}_{\text {ave }}$ for the mean and a gain $\boldsymbol{g}_{\text {std }}$ for the standard deviation can be expressed with

$$
\left\{\begin{array}{l}
\boldsymbol{g}_{\mathrm{ave}}=100 \frac{\left|E\left[\boldsymbol{d}_{m+s}^{a}\right]\right|-\left|E\left[\boldsymbol{d}_{m+i}^{a}\right]\right|}{\left(\left|E\left[\boldsymbol{d}_{m+s}^{a}\right]\right|+\left|E\left[\boldsymbol{d}_{m+i}^{a}\right]\right|\right) / 2} \\
\boldsymbol{g}_{\mathrm{std}}=100 \frac{\operatorname{Std}\left[\boldsymbol{d}_{m+s}^{a}\right]-\operatorname{Std}\left[\boldsymbol{d}_{m+i}^{a}\right]}{\left(\operatorname{Std}\left[\boldsymbol{d}_{m+s}^{a}\right]+\operatorname{Std}\left[\boldsymbol{d}_{m+i}^{a}\right]\right) / 2}
\end{array}\right.
$$

When the difference $\boldsymbol{d}_{m+i}^{a}$ between the independent observations and the analysis of MLS and LATMOS-IASI data is the same on average than the difference $\boldsymbol{d}_{m+s}^{a}$ between the independent observations and the analysis of MLS and SCIAMACHY data, the gain $\boldsymbol{g}_{\text {ave }}$ is null. When the difference $\boldsymbol{d}_{m+i}^{a}$ is lower than the difference $\boldsymbol{d}_{m+s}^{a}$, the gain is positive, with an extreme value of $200 \%$ when $\boldsymbol{d}_{m+i}^{a}=0$. On the opposite, the gain is negative when the difference $\boldsymbol{d}_{m+i}^{a}$ is higher than the difference $\boldsymbol{d}_{m+s}^{a}$. The behaviour of $\boldsymbol{g}_{\text {std }}$ is similar.

\subsection{Statistics on the LATMOS-IASI data by comparison with ozone analysis}

The time average of all the computed departures between the LATMOS-IASI data and our combined MLS and SCIAMACHY analysis, is given in Fig. 10 where the daytime and nighttime measurements have been dissociated. It shows that the systematic difference between the LATMOS-IASI data and the analysis lies between $2 \%$ and $8 \%$ which is consistent with the conclusions of Boynard et al. (2009).

The largest discrepancies are found at low and midlatitudes. They could be the result of the presence of aerosols in large concentration whose signature is better seen in the IR sensor of the IASI instrument than in the SCIAMACHY sensor. At low and mid-latitudes, the LATMOS-IASI data overestimates the total ozone column by $6 \%$ on average. The maximums differences are reached over the Pacific and the Atlantic Oceans with values of $11 \%$ and $13 \%$, respectively while the difference is lower over the Indian Ocean. The overestimation of the LATMOS-IASI ozone data is also large in the vicinity of the desert regions of the North Africa and the Persian Gulf. These trends are similar for the daytime and the nighttime data, even if the bias is lower for daytime measurements. However, over Australia, the daytime and nighttime differences show an opposite sign.
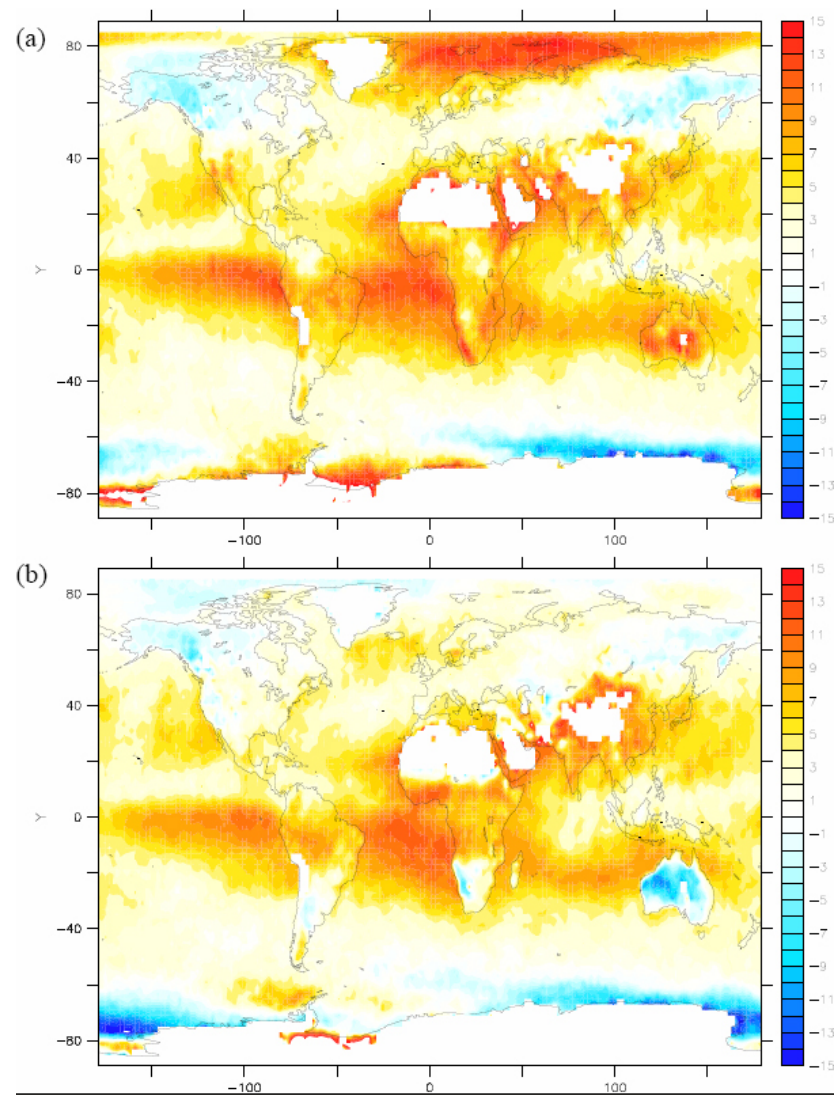

Fig. 10. Average of the difference in $\%$ between the LATMOS-IASI ozone data minus the co-located combined MLS and SCIAMACHY ozone analysis normalized by the IASI measurement, for the period 1 August to 31 December 2007. (a) Nighttime LATMOS-IASI data. (b) Daytime LATMOS-IASI data.

Over Europe and North America, there is a good agreement between the LATMOS-IASI data and our analysis, especially during the daytime. Nevertheless, the LATMOSIASI data underestimates the total ozone over icy regions such as Siberia and Canada. In those regions the algorithm could still suffer from inadequate prescription of the ground emissivity. Ground based temperatures being low over icy regions, the background IR signal is weak and can lead to erroneous ozone values. This effect is increased over ocean as it is combined with weak thermal contrast and low temperature (Clerbaux et al., 2009). This explains why the LATMOS-IASI data overestimates the total ozone over the Arctic ocean, with values ranging from about $10 \%$ to $15 \%$ and with maxima at night.

Figure 11 shows the standard deviation of the ensemble of departures between the LATMOS-IASI data and our combined MLS and SCIAMACHY analysis, for the daytime and nighttime measurements. As explained previously, we assume that this standard deviation can be attributed to the standard deviation of the LATMOS-IASI observation error. 

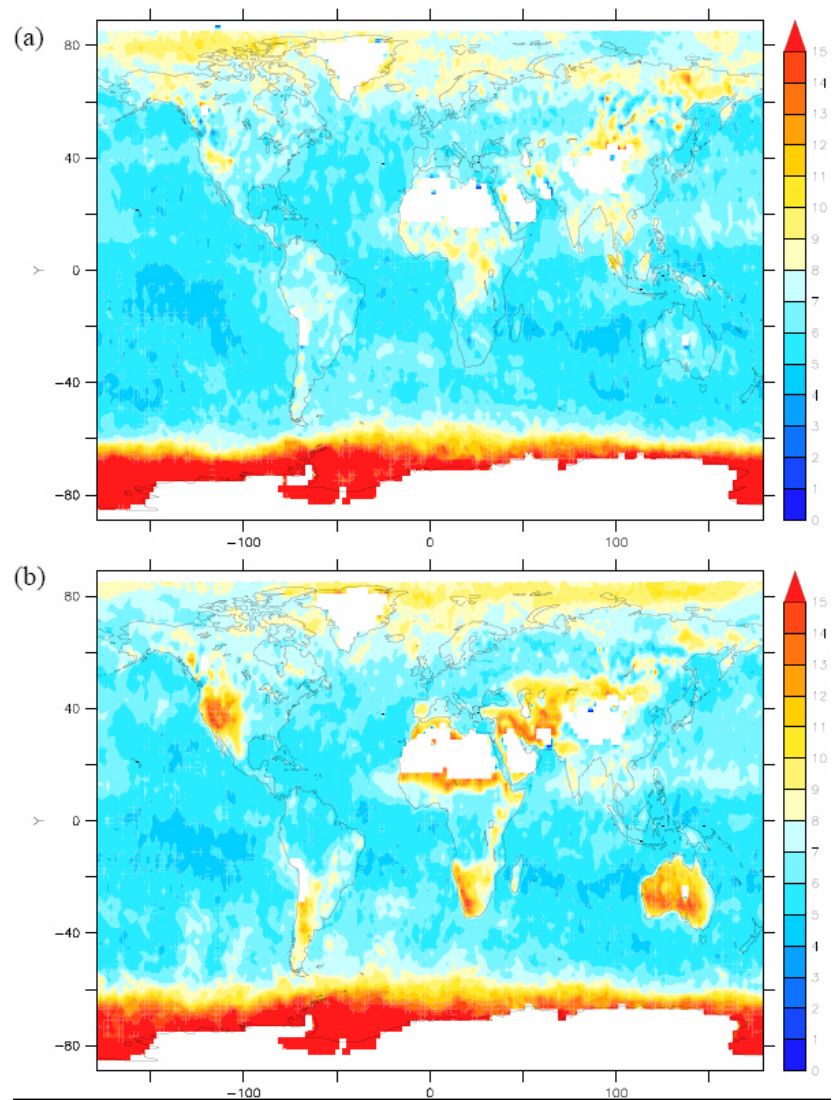

Fig. 11. Same as Fig. 10 for the standard deviation.

Thus, the figure shows that the random observation error of the LATMOS-IASI data is about $7 \%$ except in polar regions and over specific regions. In particular, the observation error can reach 10 to $15 \%$ over dry regions like Australia, North Africa or China and in a lesser extent, over the west coast of the United States, the west coast of the South Africa and the south part of the South America. The error also grows significantly over the polar regions and reaches $10 \%$ for the North and $40 \%$ for the South. This largest error seems to match the distribution of the ice caps. In addition to the effect due to the low ground temperatures, as the ozone concentrations are small over the SPR, the IR signal is weaker and noisier and the retrieval is less accurate. In that case, a larger weight is given by the neural network algorithm to the mean climatological ozone profiles.

The LATMOS neural network algorithm is based on a constant ground emissivity of 0.9813 (Turquety et al., 2004). It was found that the bias of the LATMOS-IASI data is higher over sandy region that have the lower ground emissivity. In order to find a link between the measurement errors and the ground types, we averaged on a $2^{\circ}$ by $2^{\circ}$ grid the surface emissivity derived from a climatology based on the MODerate resolution Imaging Spectroradiometer (MODIS) sensor
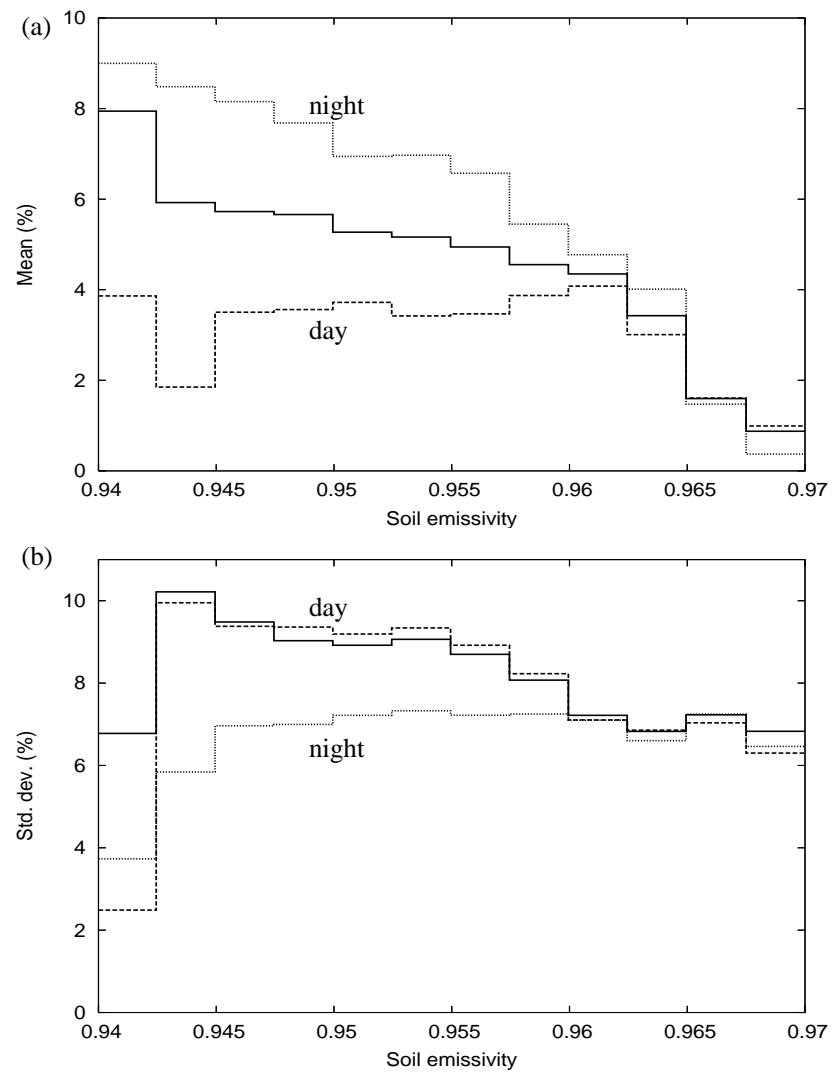

Fig. 12. Mean over the globe of the (a) average and (b) standard deviation of the difference in \% between the LATMOS-IASI ozone data minus the co-located combined MLS and SCIAMACHY ozone analysis normalized by the IASI measurement, as a function of the ground emissivity, for the period 1 August to 31 December 2007. The black line represents the daytime and nighttime data. The dotted line represents the nighttime data. The dash line represents the daytime data.

(Wan , 2008). Then, we calculated the average of the bias and standard deviation of the LATMOS-IASI data for each class of ground emissivity. The upper panel of Fig. 12 shows that as expected the bias increases as the ground emissivity deviates the value of 0.9813 . But, this behaviour is mainly driven by the nighttime measurements. The bias is higher for low values (near 0.94) that correspond to desert regions such as Africa, Persian Gulf, and Australia. The bias is lower for high values (near 0.97) that correspond to North of Europe, Canada and most of South America. The oceans emissivity is assumed to be constant (with a value of 0.963 ), and the upper panel of the figure does not show any specific behaviour around this value. Thus, the retrieval algorithm gives stable products over the oceans and the impact on the algorithm of the aerosol contents should be further investigated.

The lower panel of Fig. 12 shows that the standard deviation is also a decreasing function of the ground emissivity. This is mainly true for the daytime measurements. The 


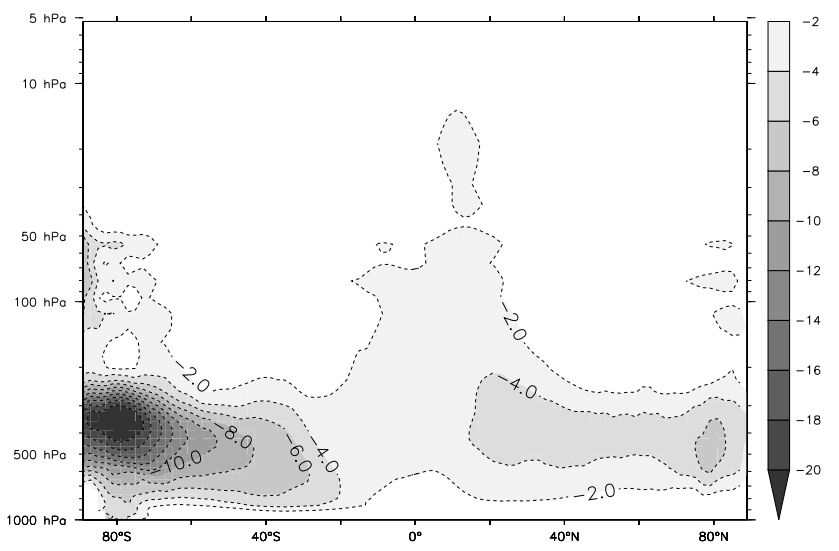

Fig. 13. Zonal average of the difference in $\%$ between the time average ozone concentrations from the combined MLS and LATMOSIASI analysis minus the ones from the combined MLS and SCIAMACHY analysis. The time average is performed on the period August to December 2007.

standard deviation of the nighttime LATMOS-IASI measurements is about $7 \%$. The standard deviation is globally larger during daytime, and it has higher values over deserts. The lower standard deviations obtained for the low ground emissivities are not significant because the population of the corresponding classes is too low.

\subsection{LATMOS-IASI assimilation}

To assimilate the LATMOS-IASI data, we first removed the monthly bias from the LATMOS-IASI super-observations. These monthly biases are a $2^{\circ}$ by $2^{\circ}$ latitude-longitude field computed from a monthly time average of the differences found between our previous analysis and the LATMOS-IASI data. No distinctions have been made between nighttime or daytime data. The diagnosed standard deviation of the LATMOS-IASI observation error obtained for the whole data (night plus day) is used to set the variance of the superobservation error required by the assimilation system. Accordingly to what was done with MLS and SCIAMACHY, we assimilate the combined MLS and LATMOS-IASI data sets. As the determination of the most adequate standard deviation and length-scales of the forecast error by an ensemble method requires a lot of computational time, we simply used those previously determined for the combined assimilation of MLS and SCIAMACHY. This allows a direct comparison between the two analyses.

The difference in terms of ozone concentration between the two analyses is illustrated by Fig. 13. It shows that, on average, the two analyses differ mainly in the troposphere over polar regions. The stratosphere is mainly constrained by the MLS data whereas the LATMOS-IASI data is the only dataset to bring information on the troposphere over the polar regions during wintertime. During summer, there is less (a) Global (428 obs.)

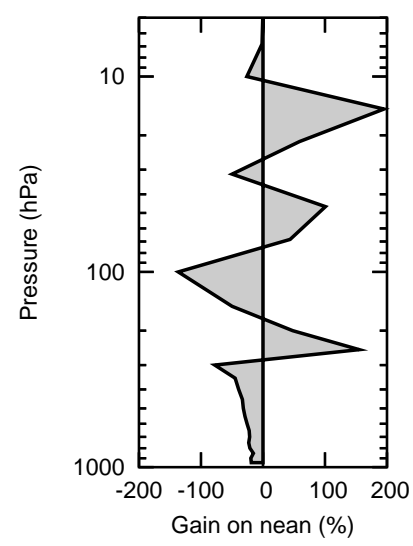

(c) $30 \mathrm{~S}$ to $30 \mathrm{~N}$ (133 obs.)

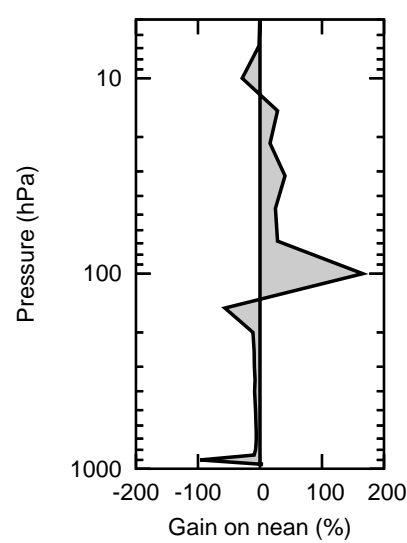

(b) $90 \mathrm{~S}$ to $60 \mathrm{~S}$ (62 obs.)

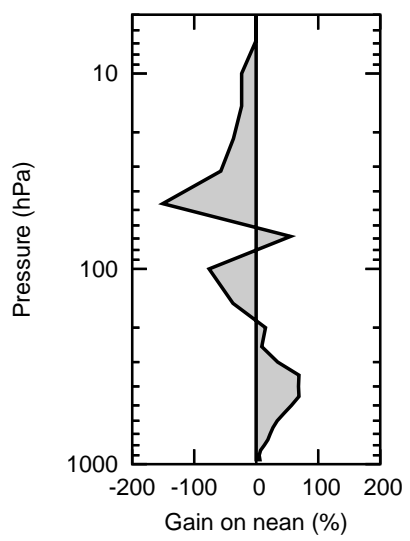

(d) $30 \mathrm{~N}$ to $60 \mathrm{~N}$ (233 obs.)

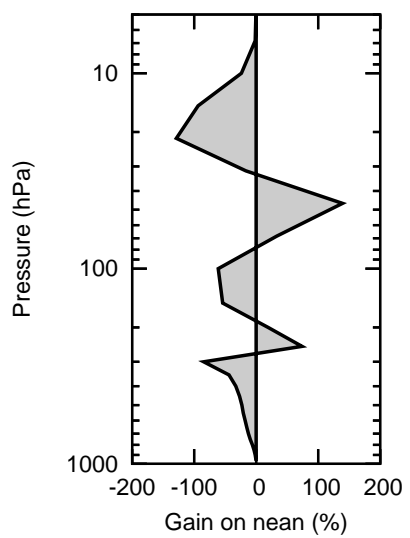

Fig. 14. Gain in $\%$ on the mean of ozonesondes minus MLS plus LATMOS-IASI analysis compared to the mean of ozonesondes minus MLS plus SCIAMACHY analysis, for the period August to December 2007.

LATMOS-IASI data over the SPR. As a consequence, the tropospheric ozone over the SPR is more constrained by the assimilation of the SCIAMACHY data than by the assimilation of the LATMOS-IASI data. This explains why the main differences in the analyses are found in the middle troposphere of the SPR, from $700 \mathrm{hPa}$ to $200 \mathrm{hPa}$. Besides, lower differences appear in the lower stratosphere, especially over the equatorial region and the SPR. Elsewhere, the differences are small.

The gain on the mean computed with the ozonesondes is displayed in Fig. 14. It shows that the gain is globally positive between $80 \mathrm{hPa}$ and $10 \mathrm{hPa}$. As the difference between MLS plus SCIAMACHY analysis and ozonesondes is very low in this altitude range, it means that there is no real improvement or damage on the ozone bias in the stratosphere by assimilating LATMOS-IASI instead of SCIAMACHY. In this region, the analysis is mainly constrained by the good-quality MLS data, and the assimilation of total ozone columns has a small impact. Below, the assimilation of 
(a) Global (428 obs.)

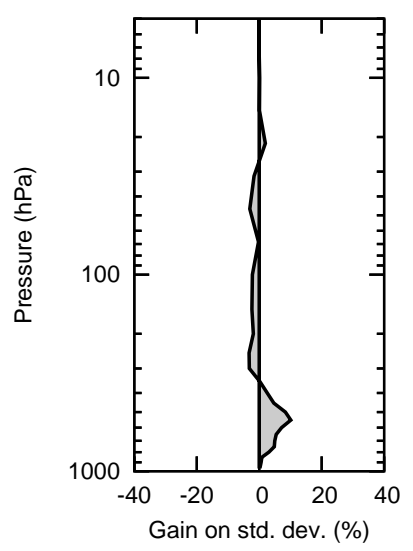

(c) $30 \mathrm{~S}$ to $30 \mathrm{~N}$ (133 obs.)

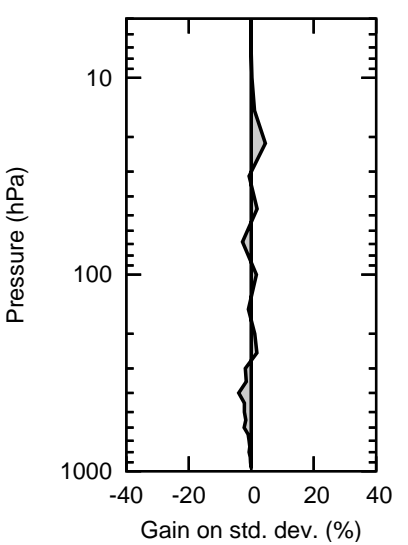

(b) $90 \mathrm{~S}$ to $60 \mathrm{~S}$ (62 obs.)

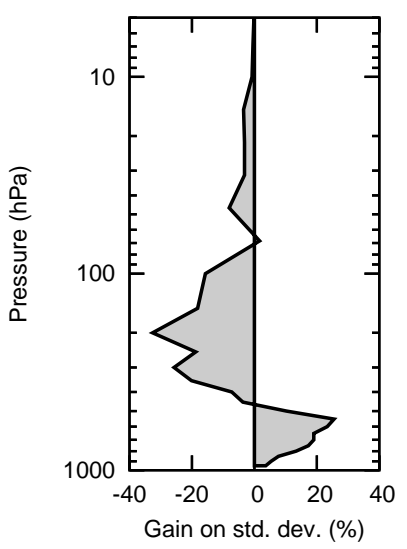

(d) $30 \mathrm{~N}$ to $60 \mathrm{~N}$ (233 obs.)

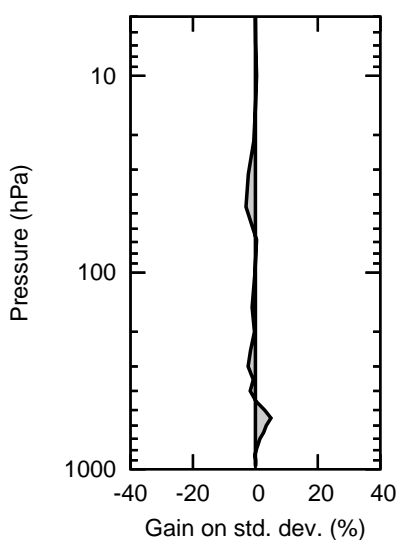

Fig. 15. Same as Fig. 14 for the standard deviation.

LATMOS-IASI reduces the tropospheric bias over the SPR, whereas the bias increases at mid-latitude of the Northern Hemisphere $(\mathrm{NH})$, between $30^{\circ} \mathrm{N}$ and $60^{\circ} \mathrm{N}$. Compared to the free simulation, the assimilation of SCIAMACHY data increases the bias in the troposphere over the SPR. As we imposed large observation errors to the LATMOS-IASI data in this region, the analysis is less constrained by their assimilation. The tropospheric ozone concentrations from the LATMOS-IASI analysis are then close to the ones of the free simulation, which are lower than those from the assimilation of SCIAMACHY data. A similar behaviour is found in the troposphere between $30^{\circ} \mathrm{N}$ and $60^{\circ} \mathrm{N}$. The assimilations of SCIAMACHY or LATMOS-IASI data both decrease the bias compared to the free simulation. But the LATMOS-IASI data are less effective due to their larger errors.

In terms of standard deviation, Fig. 15 shows that there is a slight global improvement in the troposphere when assimilating LATMOS-IASI data instead of SCIAMACHY ones. The improvements are mainly visible over the SPR. The standard deviation computed with the MLS and LATMOSIASI analysis is close to the one computed with the MLS analysis between $200 \mathrm{hPa}$ and $500 \mathrm{hPa}$. Notwithstanding,
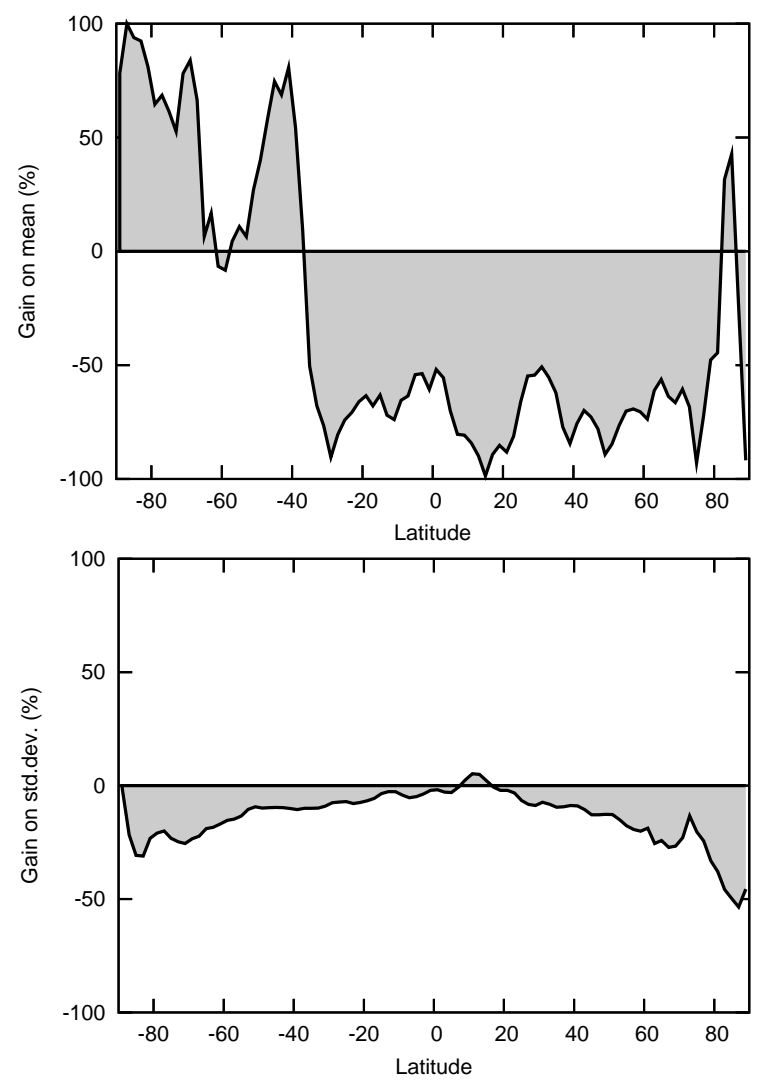

Fig. 16. Gain in \% on (a) mean and on (b) standard deviation of OMI-DOAS minus MLS and LATMOS-IASI analysis compared to OMI-DOAS minus MLS and SCIAMACHY analysis, for the period August to December 2007.

below $500 \mathrm{hPa}$, the assimilation of the combined MLS and LATMOS-IASI data reduces the standard deviation compared to the combined MLS and SCIAMACHY analysis.

The gains on the mean and on the standard deviation, considering the OMI-DOAS total columns, are displayed on Fig. 16. This gain is positive over the SPR till $40^{\circ} \mathrm{S}$. This comes from the contribution of the lower stratosphere and troposphere, as found previously. Elsewhere, the bias increases (plus $2 \%$ to $4 \%$ ) with the assimilation of the LATMOS-IASI data compared to the assimilation of the SCIAMACHY ones. As the observation error on the SCIAMACHY data is lower than the ones on the LATMOS-IASI data, the assimilation of the LATMOS-IASI data gives less constrains on the computed ozone columns. This explains why the bias with OMI-DOAS is increased while assimilating LATMOS-IASI instead of SCIAMACHY ones.

The gain on the standard deviation of the analysed total ozone column against OMI-DOAS data is mostly negative (bottom panel of Fig. 16). Between $40^{\circ} \mathrm{S}$ and $40^{\circ} \mathrm{N}$, the gain is lower than $-10 \%$ which signifies an increase of $10 \%$ on the standard deviation between the two analyses. Over the polar regions, the gain is slightly increasing. 


\section{Conclusions}

For a period of five months which spans from August to December 2007, the MetOp-A/IASI initial data set provided by the LATMOS inversion algorithm was compared to a four dimensional ozone field. This field results from the combined assimilation of ozone profiles from the MLS limb instrument and of total ozone columns from the SCIAMACHY nadir instrument. In comparison with ozone soundings and OMI-DOAS total ozone columns, we found that this analysed ozone field has low bias for the total columns (below $1.5 \%$ ) and for vertical profiles in the stratosphere (below 3\%). Its standard deviation is between $10 \%$ and $20 \%$ in the stratosphere and between $30 \%$ and $50 \%$ in the troposphere. Its standard deviation in terms of total ozone columns is mainly between $3 \%$ and $6 \%$. Therefore, this analysed ozone field was chosen as a reference to compare with day/night LATMOS-IASI data. As daytime and nighttime IASI observations have different vertical sensitivities and accuracies, the comparison was performed separately. Thanks to this comparison, it is estimated that the LATMOS-IASI data tends to overestimate the total ozone columns by $2 \%$ to $8 \%$, which is consistent with the findings of Boynard et al. (2009). The maximum overestimation is first encountered over the equatorial region with values slightly higher for the nighttime data. This is probably due to the presence of aerosols in this region. The overestimation is also maximum in the vicinity of desert regions for daytime and nighttime data, and for the nighttime over the Arctic ocean covered by ice caps. The bias is related to the difficulty of the neural network algorithm to account for the ground emissivity variability over sandy regions, and to the weak IR signal due to the low ground temperatures over icy regions. The bias is also enhanced by the lack of information due to the unused averaging kernels. The random observation error of the LATMOS-IASI night/day data is about $7 \%$ except over polar and dry regions where it is higher for the daytime data. Over sandy regions, this is also related to the ground emissivities. Over polar regions, this is due to the large weight given to mean climatological ozone profiles, and to an important noise due to smaller ozone concentrations.

A new set of LATMOS-IASI data was built removing the difference with the MLS and SCIAMACHY analysis, and specifying the standard deviation of their observation error. This LATMOS-IASI data set was assimilated in combination with the MLS data. The combined MLS and LATMOSIASI analysis agrees well with the MLS and SCIAMACHY one, with the main differences located in the troposphere and lower stratosphere over the SPR. Those differences are mainly driven by the lack of SCIAMACHY measurements during polar night, and by the fact that the model is less constrained by the LATMOS-IASI data due to their higher errors (about 7\%) compared to SCIAMACHY one (about 1\%).

This work is first attempt to assimilate the IASI ozone data into a CTM. To further explore the potential of the IASI data, many improvements would be required. First, the quality of the retrievals can be increased in specific regions by an improved training of the neural network algorithm for these specific situations, e.g. with more detailed emissivity databases. In the near future, emissivity products should also be available as a METOP product. It would be also interesting to separate in the assimilation process, daytime from nighttime data and, given their own errors characteristics, to explore their relative contributions to the analysis.

Secondly, in terms of assimilation, one major expected improvement would be the use of averaging kernels, given that the SCIAMACHY and IASI vertical sensitivities differ. Here also, the distinction between daytime and nighttime IASI data will be important. Using appropriate averaging kernels, a new ensemble of assimilation would be carried on in order to extract information on the covariance matrix of the forecast error. This is an important ingredient that can significantly improve our analysis system.

Finally, in order to make the best use of the whole information from the high horizontal IASI resolution, it would be interesting the increase the model grid resolution to avoid the use of super-observations. Going towards higher resolution, we also expect to gain in model accuracy due to a better representation of the horizontal gradients. Current model developments will allow us to use grid resolutions below $1^{\circ}$ in the near future.

Acknowledgements. IASI has been developed and built under the responsibility of the Centre National d'Etudes Spatiales (CNES, France). It is flown onboard the Metop satellites as part of the EUMETSAT Polar System. The IASI L1 data are received through the EUMETCast near real time data distribution service.

The authors would like to thank O. Pannekoucke for his previous collaboration on the forecast error parameterisation and I. Sandu for her advices on this paper.

The development of the MOCAGE-PALM assimilation system has benefit from the support of the Ether centre for atmospheric chemistry products and services (http://munk.ipsl.jussieu.fr/), and the French ADOMOCA project within the LEFE programs (http://www.insu.cnrs.fr/co/lefe).

Edited by: A. Richter

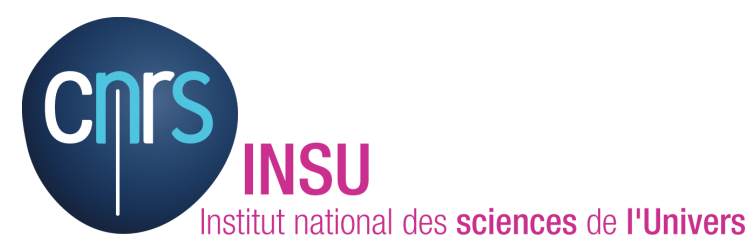

The publication of this article is financed by CNRS-INSU. 


\section{References}

Balis, D., Kroon, M., Koukouli, M. E., Brinksma, E. J., Labow, G., Veefkind, J. P., and McPeters R. D.: Validation of Ozone Monitoring Instrument total ozone column measurements using Brewer and Dobson spectrophotometer ground-based observations, J. Geophys. Res., 112, D24S46, doi:10.1029/2007JD008796, 2007.

Belo Pereira, M. and Berre, L.: The use of an Ensemble approach to study the Background Error Covariances in a Global NWP model, Mon. Weather Rev., 134, 2466-2489, 2006.

Bousserez, N., Attié, J.-L., Peuch, V.-H., Michou, M., Pfister, G., Edwards, D., Emmons, L., Mari, C., Barret, B., Arnold, S. R., Heckel, A., Richter, A., Schlager, H., Lewis, A., Avery, M., Sachse, G., Browell, E. V., and Hair, J. W.: Evaluation of the MOCAGE chemistry transport model during the ICARTT/ITOP experiment, J. Geophys. Res., 112, D10S42, doi:10.1029/2006JD007595, 2007.

Bovensmann, H., Burrows, J. P., Buchwitz, M., Frerick, J., Noël, S., Rozanov, V. V., Chance, K. V., and Goede, A. H. P.: SCIAMACHY - Mission objectives and measurement modes, J. Atmos. Sci., 56, 127-150, 1999.

Boynard, A., Clerbaux, C., Coheur, P.-F., Hurtmans, D., Turquety, S., George, M., Hadji-Lazaro, J., Keim, C., and Meyer-Arnek, J.: Measurements of total and tropospheric ozone from IASI: comparison with correlative satellite and ozonesonde observations, Atmos. Chem. Phys. Discuss., 9, 10513-10548, 2009, http://www.atmos-chem-phys-discuss.net/9/10513/2009/.

Buis, S., Piacentini, A., and Déclat, D.: PALM: A Computational framework for assembling high performance computing applications, Concurrency Computat.: Pract. Exper., 18(2), 247-262, 2006.

Caplan, P., Derber, J., Gemmill, W., Hong, S.-Y., Pan, H.-L., and Parrish, D.: Changes to the 1995 NCEP operational mediumrange forecast model analysis-forecast system, Weather Forecast., 12, 581-594, 1997.

Cariolle, D. and Teyssèdre, H.: A revised linear ozone photochemistry parameterization for use in transport and general circulation models: multi-annual simulations, Atmos. Chem. Phys., 7, 2183-2196, 2007, http://www.atmos-chem-phys.net/7/2183/2007/.

Clerbaux, C., Hadji-Lazaro, J., Turquety, S., Mégie, G., and Coheur, P.-F.: Trace gas measurements from infrared satellite for chemistry and climate applications, Atmos. Chem. Phys., 3, 14951508, 2003, http://www.atmos-chem-phys.net/3/1495/2003/.

Clerbaux, C., Boynard, A., Clarisse, L., George, M., Hadji-Lazaro, J., Herbin, H., Hurtmans, D., Pommier, M., Razavi, A., Turquety, S., Wespes, C., and Coheur, P.-F.: Monitoring of atmospheric composition using the thermal infrared IASI/MetOp sounder, Atmos. Chem. Phys. Discuss., 9, 8307-8339, 2009,

http://www.atmos-chem-phys-discuss.net/9/8307/2009/.

Derber, J. C. and Wu, W.-S.: The use of TOVS cloud-cleared radiances in the NCEP SSI analysis system, Mon. Weather Rev., 126, 2287-2299, 1998.

Desroziers, G., Berre, L., Chapnik B., and Poli, P.: Diagnosis of observation, background and analysis-error statistics in observation space, Q. J. Roy. Meteor. Soc., 131(613), 3385-3396, 2005.

Dethof, A.: Assimilation of ozone retrievals from the MIPAS instrument onboard ENVISAT, ECMWF Tech. Memo., 428, 2003.
Dufour, A., Amodei, M., Ancellet, G., and Peuch, V.-H.: Observed and modelled "chemical weather" during ESCOMPTE, Atmos. Res., 74, 161-189, 2004.

Errera, Q. and Fonteyn, D.: Four-dimensional variational chemical data assimilation of CRISTA stratospheric measurements, J. Geophys. Res., 106, 12253-12265, 2001.

Eskes, H. J, van Velthoven, P. F. J., Valks, P. J. M., and Kelder, H. M.: Assimilation of GOME total-ozone satellite observations in a three-dimensional tracer-transport model, Q. J. Roy. Meteor. Soc., 129, 1663-1681, 2003.

Eskes, H. J., van der A, R. J., Brinksma, E. J., Veefkind, J. P., de Haan, J. F., and Valks, P. J. M.: Retrieval and validation of ozone columns derived from measurements of SCIAMACHY on Envisat, Atmos. Chem. Phys. Discuss., 5, 4429-4475, 2005, http://www.atmos-chem-phys-discuss.net/5/4429/2005/.

Fisher, M. and Anderson, E.: Developments in 4D-Var and Kalman Filtering, ECMWF Technical Memorandum, 347, 38 pp., 2001.

Fortuin, J. P. F. and Kelder, H.: An ozone climatology based on ozonesonde and satellite measurements, J. Geophys. Res., 103, 31, 709-734, 1998.

Froidevaux, L., Jiang, Y. B., Lambert, A., Livesey, N. J., Read, W. G., Waters, J. W., Browell, E. V., Hair, J. W., Avery, M. A., McGee, T. J., Twigg, L. W., Sumnicht, G. K., Jucks, K. W., Margitan, J. J., Sen, B., Stachnik, R. A., Toon, G. C., Bernath, P. F., Boone, C. D., Walker, K. A., Filipiak, M. J., Harwood, R. S., Fuller, R. A., Manney, G. L., Schwartz, M. J., Daffer, W. H., Drouin, B. J., Cofield, R. E., Cuddy, D. T., Jarnot, R. F., Knosp, B. W., Perun, V. S., Snyder, W. V., Stek, P. C., Thurstans, R. P., and Wagner, P. A.: Validation of Aura Microwave Limb Sounder stratospheric ozone measurements, J. Geophys. Res., 113, D15S20, doi:10.1029/2007JD008771, 2008.

Geer, A. J., Lahoz, W. A., Bekki, S., Bormann, N., Errera, Q., Eskes, H. J., Fonteyn, D., Jackson, D. R., Juckes, M. N., Massart, S., Peuch, V.-H., Rharmili, S., and Segers, A.: The ASSET intercomparison of ozone analyses: method and first results, Atmos. Chem. Phys., 6, 5445-5474, 2006, http://www.atmos-chem-phys.net/6/5445/2006/.

Geer, A. J., Lahoz, W. A., Jackson, D. R., Cariolle, D., and McCormack, J. P.: Evaluation of linear ozone photochemistry parametrizations in a stratosphere-troposphere data assimilation system, Atmos. Chem. Phys., 7, 939-959, 2007, http://www.atmos-chem-phys.net/7/939/2007/.

Jiang, Y. B., Froidevaux, L., Lambert, A., Livesey, N. J., Read, W. G., Waters, J. W., Bojkov, B., Leblanc, T., McDermid, I. S., Godin-Beekmann, S., Filipiak, M. J., Harwood, R. S., Fuller, R. A., Daffer, W. H., Drouin, B. J., Cofield, R. E., Cuddy, D. T., Jarnot, R. F., Knosp, B. W., Perun, V. S., Schwartz, M. J., Snyder, W. V., Stek, P. C., Thurstans, R. P., Wagner, P. A., Allaart, M., Andersen, S. B., Bodeker, G., Calpini, B., Claude, H., Coetzee, G., Davies, J., De Backer, H., Dier, H., Fujiwara, M., Johnson, B., Kelder, H., Leme, N. P., König-Langlo, G., Kyro, E., Laneve, G., Fook, L. S., Merrill, J., Morris, G., Newchurch, M., Oltmans, S., Parrondos, M. C., Posny, F., Schmidlin, F., Skrivankova, P., Stubi, R., Tarasick, D., Thompson, A., Thouret, V., Viatte, P., Vömel, H., von Der Gathen, P., Yela, M., and Zablocki, G.: Validation of Aura Microwave Limb Sounder Ozone by ozonesondeand lidar measurements, J. Geophys. Res., 112, D24S34, doi:10.1029/2007JD008776, 2007. 
Lahoz, W. A., Errera, Q., Swinbank, R., and Fonteyn, D.: Data assimilation of stratospheric constituents: a review, Atmos. Chem. Phys., 7, 5745-5773, 2007a, http://www.atmos-chem-phys.net/7/5745/2007/.

Lahoz, W. A., Geer, A. J., Bekki, S., Bormann, N., Ceccherini, S., Elbern, H., Errera, Q., Eskes, H. J., Fonteyn, D., Jackson, D. R., Khattatov, B., Marchand, M., Massart, S., Peuch, V.-H., Rharmili, S., Ridolfi, M., Segers, A., Talagrand, O., Thornton, H. E., Vik, A. F., and von Clarmann, T.: The Assimilation of Envisat data (ASSET) project, Atmos. Chem. Phys., 7, 1773-1796, 2007b, http://www.atmos-chem-phys.net/7/1773/2007/.

Levelt, P. F., van den Oord, G. H. J., Dobber, M. R., Malkki, A., Visser, H., de Vries, J., Stammes, P., Lundell, J. O. V., and Saari, H.: The Ozone Monitoring Instrument, Geosci. Remote Sens., 44(5), 1093-1101, 2006.

Livesey, N. J., Filipiak, M. J., Froidevaux, L., Read, W. G., Lambert, A., Santee, M. L., Jiang, J. H., Pumphrey, H. C., Waters, J. W., Cofield, R. E., Cuddy, D. T., Daffer, W. H., Drouin, B. J., Fuller, R. A., Jarnot, R. F., Jiang, Y. B., Knosp, B. W., Li, Q. B., Perun, V. S., Schwartz, M. J., Snyder, W. V., Stek, P. C., Thurstans, R. P., Wagner, P. A., Avery, M., Browell, E. V., Cammas, J.-P., Christensen, L. E., Diskin, G. S., Gao, R.-S., Jost, H.-J., Loewenstein, M., Lopez, J. D., Nedelec, P., Osterman, G. B., Sachse, G. W., and Webster, C. R.: Validation of Aura Microwave Limb Sounder O3 and CO observations in the upper troposphere and lower stratosphere, J. Geophys. Res., 113, D15S02, doi:10.1029/2007JD008805, 2008.

Logan, J. A.: An analysis of ozonesonde data for the troposphere: Recommendations for testing 3-D models and development of a gridded climatology for tropospheric ozone, J. Geophys. Res., 104(16), 115-149, 1999.

Massart, S., Cariolle, D., and Peuch, V.-H.: Vers une meilleure représentation de la distribution et de la variabilité de l'ozone atmosphérique par l'assimilation des données satellitaires, CR. Acad. Sci., 337, 1305-1310, 2005a.

Massart, S., Manzoni, H., Cariolle, D., Peuch, V.-H., and Piacentini, A.: Validation of a 3D-Fgat assimilation of MIPAS ozone profiles in a global chemistry and transport model, Fourth WMO Symposium on Assimilation of Observations in Meteorology and Oceanography, Prague, Czech Republic, April 2005b.

Massart, S., Piacentini, A., Cariolle, D., El Amraoui, L., and Semane, N.: Assessment of the quality of the ozone measurements from the Odin/SMR instrument using data assimilation, Can. J. Phys., 85, 1209-1223, 2007.

Migliorini, S., Piccolo, C., and Rodgers, C. D.: Intercomparison of direct and indirect measurements: Michelson Interferometer for Passive Atmospheric Sounding (MIPAS) versus sonde ozone profiles, J. Geophys. Res., 109, D19316, doi:10.1029/2004JD004988, 2004.

Monge-Sanz, B., Chipperfield, M. P., Simmons, A., and Uppala, S.: Mean age of air and transport in a CTM: Comparison of different ECMWF analyses, Geophys. Res. Lett., 34, L04801, doi:10.1029/2006GL028515, 2007.

Pannekoucke, O. and Massart, S.: Estimation of the local diffusion tensor and normalization for heterogeneous correlation modelling using a diffusion equation, Q. J. Roy. Meteor. Soc., 134(635), 1425-1438, doi:10.1002/qj.288, 2008.

Pougatchev, N., August, T., Calbet, X., Hultberg, T., Oduleye, O., Schlüssel, P., Stiller, B., Germain, K. S., and Bingham, G.: IASI temperature and water vapor retrievals - error assessment and validation, Atmos. Chem. Phys. Discuss., 9, 7971-7989, 2009, http://www.atmos-chem-phys-discuss.net/9/7971/2009/.

Ricaud, P., Attié, J.-L., Teyssèdre, H., El Amraoui, L., Peuch, V.H., Matricardi, M., and Schlüssel, P.: Equatorial total column of nitrous oxide as measured by IASI on MetOp-A: implications for transport processes Atmos. Chem. Phys., 9, 3947-3956, 2009, http://www.atmos-chem-phys.net/9/3947/2009/.

Smit, H. G. J., Strater, W., Helten, M., Kley, D., Ciupa, D., Claude, H. J., Kohler, U., Hoegger, B., Levrat, G., Johnson, B., Oltmans, S. J., Kerr, J. B., Tarasick, D. W., Davies, J., Shitamichi, M., Srivastav, S. K., Vialle, C., and Velghe, G., JOSIE: The 1996 WMO International intercomparison of ozonesondes under quasi flight conditions in the environmental simulation chamber at Julich, in: Proceedings of the XVIII Quadrennial Ozone Symposium, edited by: Bojkov, R. and Visconti, G., L'Aquila, Italy, September 1996, 971-974, 1998.

Teyssèdre, H., Michou, M., Clark, H. L., Josse, B., Karcher, F., Olivié, D., Peuch, V.-H., Saint-Martin, D., Cariolle, D., Attié, J.-L., Nédélec, P., Ricaud, P., Thouret, V., van der A, R. J., VolzThomas, A., and Chéroux, F.: A new tropospheric and stratospheric Chemistry and Transport Model MOCAGE-Climat for multi-year studies: evaluation of the present-day climatology and sensitivity to surface processes, Atmos. Chem. Phys., 7, 58155860, 2007, http://www.atmos-chem-phys.net/7/5815/2007/.

Thompson, A. M., Witte, J. C., McPeters, R. D., Oltmans, S. J., Schmidlin, F. J., Logan, J. A., Fujiwara, M., Kirchhoff, V. W. J. H., Posny, F., Coetzee, G. J. R., Hoegger, B., Kawakami, S., Ogawa, T., Johnson, B. J., Vömel, H., and Labow, G.: Southern Hemisphere Additional Ozonesondes (SHADOZ) 1998-2000 tropical ozone climatology 1. Comparison with Total Ozone Mapping Spectrometer (TOMS) and ground-based measurements, J. Geophys. Res., 108, 8238, doi:10.1029/2001JD000967, 2003.

Turquety, S., Hadji-Lazaro, J., Clerbaux, C., Hauglustaine, D. A., Clough, S. A., Cassé, V., Schlüssel, P., and Mégie, G.: Operational trace gas retrieval algorithm for the Infrared Atmospheric Sounding Interferometer, J. Geophys. Res., 109, D21301, doi:10.1029/2004JD004821, 2004.

Valks, P. and van Oss, R.: TOGOMI Algorithm Theoretical Basis Document, Issue 1.2, TOGOMI/KNMI/ATBD/001, KNMI/ESA, November 2003.

Veefkind, J. P., de Haan, J. F., Brinksma, E. J., Kroon, M., and Levelt, P. F.: Total Ozone from the Ozone Monitoring Instrument (OMI) Using the DOAS technique, Geo. Rem. Sens., 44, 5, 1239-1244, doi:10.1109/TGRS.2006.871204, 2006.

Wan, Z.: New refinements and validation of the MODIS LandSurface Temperature/Emissivity products, Remote Sens. Environ., 112, 59-74, 2008.

Waters, J. W., Froidevaux, L., Harwood, R. S., Jarnot, R. F., Pickett, H. M., Read, W. G., Siegel, P. H., Cofield, R. E., Filipiak, M. J., Flower, D. A., Holden, J. R., Lau, G. K., Livesey, N. J., Manney, G. L., Pumphrey, H. C., Santee, M. L., Wu, D. L., Cuddy, D. T., Lay, R. R., Loo, M. S., Perun, V. S., Schwartz, M. J., Stek, P. C., Thurstans, R. P., Boyles, M. A., Chandra, K. M., Chavez, M. C., Chen, G.-S., Chudasama, B. V., Dodge, R., Fuller, R. A., Girard, M. A., Jiang, J. H., Jiang, Y., Knosp, B. W., LaBelle, R. C., Lam, J. C., Lee, K. A., Miller, D., Oswald, J. E., Patel, N. C., Pukala, D. M., Quintero, O., Scaff, D. M., Van Snyder, W., Tope, M. C., 
Wagner, P. A., and Walch, M. J.: The Earth observing system microwave limb sounder (EOS MLS) on the aura Satellite, IEEE T. Geosci. Remote, 44, 1075-1092, 2006.
Weaver, A. and Courtier, P.: Correlation modelling on the sphere using a generalized diffusion equation, Q. J. Roy. Meteor. Soc., 127, 1815-1846, 2001 